\title{
Review Article \\ Glomerular Disease in Patients with Infectious Processes Developing Antineutrophil Cytoplasmic Antibodies
}

\author{
Konstantin N. Konstantinov, ${ }^{1}$ Suzanne N. Emil, ${ }^{1}$ Marc Barry, ${ }^{2}$ \\ Susan Kellie, ${ }^{3}$ and Antonios H. Tzamaloukas ${ }^{4}$ \\ ${ }^{1}$ Division of Rheumatology, Department of Medicine, Raymond G. Murphy VA Medical Center, \\ University of New Mexico School of Medicine, Albuquerque, NM 87131, USA \\ ${ }^{2}$ Department of Pathology, University of New Mexico School of Medicine, MSC08 4640, BMSB, Room 335, \\ University of New Mexico, Albuquerque, NM 87131, USA \\ ${ }^{3}$ Division of Infectious Diseases, Department of Medicine, Raymond G. Murphy VA Medical Center, \\ University of New Mexico School of Medicine, Albuquerque, NM 87131, USA \\ ${ }^{4}$ Division of Nephrology, Department of Medicine, Raymond G. Murphy VA Medical Center, \\ University of New Mexico School of Medicine, VA Medical Center (111C), 1501 San Pedro, SE, Albuquerque, NM 87131, USA
}

Correspondence should be addressed to Antonios H. Tzamaloukas; antonios.tzamaloukas@med.va.gov

Received 18 October 2012; Accepted 6 November 2012

Academic Editors: G. Gonlusen, M. S. Mubarak, and S. Nasr

Copyright (C) 2013 Konstantin N. Konstantinov et al. This is an open access article distributed under the Creative Commons Attribution License, which permits unrestricted use, distribution, and reproduction in any medium, provided the original work is properly cited.

To identify differences in treatment and outcome of various types of glomerulonephritis developing in the course of infections triggering antineutrophil cytoplasmic antibody (ANCA) formation, we analyzed published reports of 50 patients. Immunosuppressives were added to antibiotics in 22 of 23 patients with pauci-immune glomerulonephritis. Improvement was noted in $85 \%$ of 20 patients with information on outcomes. Death rate was $13 \%$. Corticosteroids were added to antibiotics in about $50 \%$ of 19 patients with postinfectious glomerulonephritis. Improvement rate was $74 \%$, and death rate was $26 \%$. Two patients with mixed histological features were analyzed under both pauci-immune and post-infectious glomerulonephritis categories. In 9 patients with other renal histology, treatment consisted of antibiotics alone (7 patients), antibiotics plus immunosuppressives (1 patient), or immunosuppressives alone (1 patient). Improvement rate was $67 \%$, permanent renal failure rate was $22 \%$, and death rate was $11 \%$. One patient with antiglomerular basement disease glomerulonephritis required maintenance hemodialysis. Glomerulonephritis developing in patients who became ANCA-positive during the course of an infection is associated with significant mortality. The histological type of the glomerulonephritis guides the choice of treatment. Pauci-immune glomerulonephritis is usually treated with addition of immunosuppressives to antibiotics.

\section{Introduction}

The reaction of the body to infections may cause secondary illnesses, such as rheumatic fever and poststreptococcal glomerulonephritis, with potentially life-threatening manifestations. An early step in the research to unravel the link between infection and secondary illness was the discovery that chronic infections trigger multiple immunological responses potentially associated with specific diseases
[1]. Infections can lead to formation of multiple autoantibodies, for example, rheumatoid factor, antinuclear antibodies (ANAs), antiphospholipid antibodies, and antineutrophil cytoplasmic antibodies (ANCAs). The development of autoantibodies in the course of an infection may or may not be associated with manifestations of autoimmune disease.

The recognition of autoimmune manifestations during the course of an infection and the decision to add specific treatment for the secondary immunological abnormality or 
to treat only the infection and monitor the patient for attenuation and disappearance of the immunological manifestations are critical tasks. The search for organ manifestations that can help the distinction between infectious and immunological manifestations can assist the diagnostic process. The kidneys, and particularly the glomeruli, are frequently affected by either the primary infectious process or the secondary immunological disease.

It has been known for a long time that glomerulonephritis may complicate a severe infection (endocarditis) [2]. Immune complex deposition in glomeruli, through either in situ formation [3] or trapping of circulating immune complexes [4], was the mechanism for glomerulonephritis following bacterial infections that was established first [5-7]. In one case of postinfectious glomerulonephritis, streptococcal antigens were found in the immune deposits in the kidney [8]. In a second case, antibodies against Enterococcus were eluded from the kidney [9].

This paper addresses glomerulonephritis associated with the formation of ANCA during the course of an infection. We identified published reports of ANCA formation during the course of infections and selected reports containing information about renal histology. We reviewed the histological types of renal lesions, the treatment of the renal disease, and the outcomes of the patients. Finally, we analyzed the pathogenesis of ANCA formation during the course of infections.

\section{ANCA Formation during the Course of Various Illnesses}

ANCA can be formed following environmental exposure (silica), use of drugs, or during the course of various disease processes. Drugs most frequently leading to ANCA formation are hydralazine, propylthiouracil, penicillamine, allopurinol, and sulfasalazine [10]. The list of medical conditions which are associated with ANCA formation during their course is expanding, like the list of drugs. These conditions are classified into one of three categories [11]. (a) Chronic inflammatory processes: rheumatoid arthritis, inflammatory bowel disease, sweet syndrome, eosinophilia-myalgia syndrome, Goodpasture syndrome [11], systemic lupus erythematosus [12], mixed connective tissue disease [13], and chronic liver disease [14] including primary sclerosing cholangitis [15] and autoimmune hepatitis [16], (b) neoplasms: solid tumors (small cell lung carcinoma, renal carcinoma, colonic carcinoma, gastric carcinoma, pancreatic tumors, and thymoma), atrial myxoma, lymphoma, myeloma, myelodysplasias and hematopoietic stem cell transplantation [11, 17-22], and (c) infections.

Although the impact of ANCA formation and ANCAassociated disease on the course of each disease category is worth studying, the relation between infection and formation of ANCA deserves special emphasis. Two lines of evidence suggest a central role for infections in the formation of ANCA. (a) Various types of ANCA formation during infections, including ANCA directed at antigens other than myeloperoxidase (MPO) or proteinase-3 (PR-3), have been explored in the laboratory. This topic will be discussed in the section on pathogenesis. (b) Clinical studies suggest that formation of ANCA in several conditions considered noninfectious, such as sclerosing cholangitis, autoimmune hepatitis, inflammatory bowel disease [23], and rheumatoid arthritis [24] is triggered by secondary infections.

The finding of ANCA positivity (as well as positive serologies for other autoantibodies such as antiphospholipid antibodies, antinuclear antibodies, etc.) during the course of an infectious process generates two critical questions. (a) Is the autoantibody only a serological test without any other clinical significance or autoantibody-mediated disease complicates the infection? The distinction is difficult because infections and immunological disease share several frequent manifestations. A careful investigation for manifestations caused by autoantibodies is warranted. (b) If clinical manifestations of autoimmune disease are found, will treatment of the infection also reverse the autoimmune manifestations, or additional measures directed towards these manifestations are needed? This constitutes a therapeutic dilemma. Autoimmune manifestations may be life threatening, but on the other hand, methods of treatment of autoimmune diseases are associated with increased risks of sepsis [25-27].

Study of the kidneys should be targeted in patients with infections and ANCA positivity because kidneys are one of the main organs affected by ANCA-associated disease. Of note is that kidneys may be affected by various pathogenetic mechanisms during the course of severe infections. In one study, the histological patterns of renal disease associated with infectious endocarditis included in descending frequency renal infarcts, approximately one-half of which were due to septic emboli, glomerulonephritis, acute interstitial nephritis, and cortical necrosis [28]. In addition, the histological picture of glomerulonephritis varies. Glomerulonephritis with immune complex deposition characterizing the classical postinfectious variety, or IgA nephropathy, and vasculitis/pauci-immune glomerulonephritis have all been described [29].

\section{Infectious Processes Associated with Formation of ANCA}

We reviewed reports of ANCA formation during the course of infections found in a PubMed search and reports found in the reference lists of the PubMed reports. We found four types of reports, laboratory studies analyzing large, usually, numbers of sera from patients with a specific infection, reviews, epidemiological studies, and clinical reports presenting details of one case or a small number of cases.

Tables 1 and 2 show categories of infectious agents associated with ANCA positivity. For infectious agents with multiple reports of ANCA association, for example, human immunodeficiency and hepatitis viruses, we selected representative articles for the list of references. The list of infections associated with ANCA formation will, in all probability, expand. New associations are continuously reported. It is probable that a few associations included in Tables 1 and 2 represent superinfection in patients with primary ANCAassociated disease, rather than ANCA formation during the course of an infection. Finally, it is possible that we missed 
TABLE 1: Viral and bacterial infections associated with ANCA formation.

\begin{tabular}{|c|c|c|c|}
\hline Virus species & References & Bacterial species & References \\
\hline $\begin{array}{l}\text { Human } \\
\text { immunodeficiency } \\
\text { virus (HIV) }\end{array}$ & [30-33] & Streptococcus & [34-36] \\
\hline Hepatitis B virus & {$[37,38]$} & Staphylococcus & {$[36,39,40]$} \\
\hline Hepatitis $C$ virus & {$[41-44]$} & Enterococcus & {$[36,40]$} \\
\hline Parvovirus B-19 & [45-48] & Bartonella & [49] \\
\hline Epstein-Barr virus & {$[46]$} & Gemella & [49] \\
\hline \multirow[t]{19}{*}{ Arbovirus } & {$[50]$} & Propionibacterium & {$[49]$} \\
\hline & & Neisseria & {$[51]$} \\
\hline & & Actinobacillus & {$[52]$} \\
\hline & & Pseudomonas & {$[53-56]$} \\
\hline & & Escherichia & {$[57]$} \\
\hline & & Bacteroides & [57] \\
\hline & & Campylobacter & {$[58]$} \\
\hline & & Helicobacter & {$[59]$} \\
\hline & & Yersinia & {$[58,60]$} \\
\hline & & Salmonella & {$[60]$} \\
\hline & & Corynebacterium & {$[61]$} \\
\hline & & Stenotrophomonas & {$[62,63]$} \\
\hline & & Klebsiella & {$[63]$} \\
\hline & & Mycoplasma & {$[64]$} \\
\hline & & Chlamydia & {$[65-67]$} \\
\hline & & Rickettsia & {$[68-70]$} \\
\hline & & Treponema & {$[71]$} \\
\hline & & Leptospira & {$[72]$} \\
\hline & & Mycobacterium & {$[73-82]$} \\
\hline
\end{tabular}

some reported infections associated with formation of ANCA despite a systematic search.

\section{Glomerulonephritis in Patients with ANCA Formation during Infectious Episodes}

We present a synthesis of published reports of infectious episodes with ANCA formation and known renal histology. These reports belong almost exclusively in the case report category. There is a paucity of systematic studies analyzing substantial numbers of patients. Therefore, the impact of ANCA formation during the course of an infectious process with glomerular involvement on the course of the renal disease, the choice of treatment, and the outcome of the patients will require further studying. It is possible that a minority (two or three) of the reports analyzed represent superinfection in patients with primary ANCA-associated disease.

We found 35 references reporting 50 patients with histologically documented glomerular disease and ANCA positivity or renal vasculitis/pauci-immune glomerulonephritis with negative ANCA serology during the course of infectious
TABLE 2: Fungal, protozoal, and multicellular parasitic infections associated with ANCA formation infections associated with ANCA formation.

\begin{tabular}{lc}
\hline Category of infectious agent & References \\
\hline Fungus species & {$[83-86]$} \\
Aspergillus & {$[87]$} \\
Histoplasma & {$[88]$} \\
Sporothrix & {$[86,89,90]$} \\
Pneumocystis & {$[91]$} \\
Paracoccidioides & {$[92,93]$} \\
Saccharomyces & \\
Protozoa & {$[94,95]$} \\
Ameba & {$[96-98]$} \\
Plasmodium & {$[99]$} \\
Leishmania & \\
Multicellular parasites & {$[100]$} \\
Echinococcus & {$[101]$} \\
Strongyloides & {$[102]$} \\
Toxocara &
\end{tabular}

episodes. Twenty references $[35,36,40,51,52,103-107$, $109,111,113-115,123-127]$ reported 27 patients with infective endocarditis, while 15 references $[39,50,62,63,108,110$, $112,116-122,128$ ] reported 23 patients with other infectious episodes. Age of the patients varied between 6 and 87 years (endocarditis 6-87, mean \pm standard deviation $44.7 \pm 21.1$ years, other infections $17-74,48.7 \pm 16.0$ years $)$. Of the 50 patients, $18(36 \%)$ were female and $32(64 \%)$ were male. There was a preponderance of male patients among subjects with endocarditis (males 20 of 27, or 74\%, females 7 of 27, or $26 \%$ ), while the percentages of females (11 of 23 , or $48 \%$ ) and males ( 12 of 23 , or $52 \%$ ) were similar in patients with other infections.

Table 3 shows the microbial etiology of the infections. Blood cultures revealed more than one species of microorganisms in several patients [51, 63, 108]. Three species of bacteria, Streptococcus, Staphylococcus, and Enterococcus, accounted for $63 \%$ of the reported episodes of infectious endocarditis and $42 \%$ of all infections reported. In patients with endocarditic due to Bartonella $[113,114]$ and Brucella [115], the diagnosis was not made by blood cultures, which were negative, but by clinical examination, echocardiography, serologic tests, and response to antibiotics. Infectious endocarditis, in the absence of positive blood cultures, was diagnosed by histological examination of cardiac valves in four patients $[123,126,127]$ and $[124,(b)]$. Endocarditis in the absence of positive blood cultures was diagnosed by clinical evaluation, echocardiographic findings, and the response to antibiotics in two patients [124, (a)] and [125]. The evolution of clinical and laboratory status under antibiotic treatment was used to diagnose an active infection other than endocarditis in one patient [114]. 
TABLE 3: Microbial species associated with ANCA formation and glomerulonephritis in 50 patients.

\begin{tabular}{|c|c|c|}
\hline Microbial species & Endocarditis references & $\begin{array}{c}\text { Other infections } \\
\text { references }\end{array}$ \\
\hline $\begin{array}{l}\text { Streptococcus } \\
\text { species }\end{array}$ & $\begin{array}{c}{[35],[36,(\mathrm{a})-(\mathrm{c})]} \\
{[51,103-107]}\end{array}$ & [108] \\
\hline $\begin{array}{l}\text { Staphylococcus } \\
\text { species }\end{array}$ & {$[36,(\mathrm{e})-(\mathrm{f})],[109]$} & {$[39,110]$} \\
\hline $\begin{array}{l}\text { Enterococcus } \\
\text { species }\end{array}$ & {$[36,(d)],[40,111]$} & {$[63]$} \\
\hline $\begin{array}{l}\text { Actinobacillus } \\
\text { actinomycetem- } \\
\text { comitans }\end{array}$ & {$[52]$} & {$[112]$} \\
\hline Bartonella species & {$[113,114]$} & \\
\hline Neisseria subflava & [51] & \\
\hline Brucella species & {$[115]$} & \\
\hline $\begin{array}{l}\text { Stenotrophomonas } \\
\text { species }\end{array}$ & & {$[62,63]$} \\
\hline $\begin{array}{l}\text { Propionibacterium } \\
\text { species }\end{array}$ & & {$[116,117]$} \\
\hline Klebsiella species & & {$[63]$} \\
\hline $\begin{array}{l}\text { Gemella } \\
\text { morbillorum }\end{array}$ & & {$[118]$} \\
\hline Escherichia coli & & {$[110]$} \\
\hline Mycoplasma & & [119] \\
\hline Arbovirus & & {$[50,(\mathrm{a})-(\mathrm{h})]$} \\
\hline Hepatitis $C$ virus & & {$[120,(\mathrm{a})$ and $(\mathrm{b})]$} \\
\hline $\begin{array}{l}\text { Human } \\
\text { immunodeficiency } \\
\text { virus }\end{array}$ & & {$[121]$} \\
\hline $\begin{array}{l}\text { Varicella-zoster } \\
\text { virus }\end{array}$ & & [122] \\
\hline
\end{tabular}

Letters following the number of a reference denote patients in reports containing more than one patient.

\section{Laboratory Tests in Patients with Infections, ANCA Positivity, and Glomerulonephritis}

Table 4 shows abnormalities in the laboratory tests in the 50 patients analyzed in this report. Anemia was almost universal. The only hematological difference between patients with endocarditis and those with other infections was a slightly higher mean white blood count in those with other infections. Among tests indicating inflammation, blood erythrocyte sedimentation rate and serum C-reactive protein were almost universally elevated, while depression of serum complement components was found in approximately half of the patients.

A variety of autoantibodies was reported with no appreciable differences between patients with endocarditis and those with other infections. ANCA positivity without any identification of ANCA specificity was reported in 9 patients $[50,121]$. The specificity of ANCA changed from p-ANCA to c-ANCA during the course of the disease in one patient [35]. Another patient had both anti-PR-3 and anti-MPO ANCA [107]. Finally, ANCA with specificities other than MPO or
PR-3 was found in two instances $[62,112]$. These findings are relevant to the discussion of formation of ANCA with various specificities during the course of infectious episodes which will follow later in this paper.

Tests less frequently reported included serum antiphospholipid antibody, which was positive in 6 of 8 patients (75\%) with endocarditis and negative in one patient with infection other than endocarditis, polyclonal elevation of immunoglobulins reported in 12 patients with endocarditis and 4 patients with other infections, and circulating immune complexes detected in 4 patients with endocarditis and 3 patients with other infections. Antiglomerular basement membrane antibody was positive in one of the five patients tested (20\%).

\section{Renal Manifestations in Patients with Infections, ANCA Positivity, and Glomerulonephritis}

Table 5 summarizes urinary and renal function findings in these patients. Reports presenting more than 3 patients tended to omit details in renal function $[36,50]$. Hematuria was almost universal. The low number of patients with dysmorphic red cells or red cell casts may reflect performance of urinalysis by automated means in a number of the instances. Pyuria was probably underreported. Some degree of proteinuria was found in all studied patients. Approximately, one third of the patients had nephrotic proteinuria. The degree of proteinuria was the only identified difference between patients with endocarditis and those with other infections. Patients with infections other than endocarditis appeared to have a higher frequency of nephrotic proteinuria. Cryoglobulinemic glomerulonephritis secondary to hepatitis C may have contributed to this finding [120]. Serum creatinine was elevated in $95 \%$ of the patients. Advanced renal failure requiring temporary or permanent dialysis was reported in $18 \%$ of the patients. It is probable that as high as $24 \%$ required dialysis.

Table 6 shows the types of renal pathology and their association with hypocomplementemia and various ANCA specificities. The classification of glomerular lesions was done by two of the authors of this report (Barry and Tzamaloukas). In a small number of cases, our characterization of the glomerular lesion differed from that of the authors of the original reports. The classification encountered the following difficulties which should be noted because they may guide future efforts. (a) Immunofluorescence and, even more frequently, electron microscopy findings, essential for the diagnosis of the type of glomerulonephritis, were missing from many reports. (b) Renal pathology in a few instances was done on autopsy material, which may have produced false negative immunofluorescence findings. (c) Information which would provide convincing evidence for a histological diagnosis was missing from several reports. (d) Several patients had a combination of features of pauci-immune glomerulonephritis and features of postinfectious glomerulonephritis with immune complex deposition. This last feature merits a few comments. 
TABLE 4: Abnormal laboratory tests in 50 patients with infections, ANCA positivity, and glomerular disease.

\begin{tabular}{|c|c|c|}
\hline Laboratory test & Number of patients tested & Percent of tests with abnormality \\
\hline \multicolumn{3}{|l|}{ Hematology } \\
\hline Anemia $^{1}$ & 23 (E: 16, O: 7) & 96 (E: 100, O: 86) \\
\hline Leucocytosis $^{2}$ & 31 (E: 14, O: 17) & 45 (E: 29, O: 59) \\
\hline Leucopenia $^{3}$ & 31 (E: 14, O: 17) & 13 (E: 21, O: 6) \\
\hline Shift to the left ${ }^{4}$ & 11 (E: 8, O: 3) & 64 (E: 63, O: 67) \\
\hline Thrombocytopenia $^{5}$ & $17(\mathrm{E}: 13, \mathrm{O}: 4)$ & 24 (E: 23, O: 25) \\
\hline \multicolumn{3}{|l|}{ Tests of inflammation } \\
\hline Elevated Erythrocyte sedimentation rate ${ }^{6}$ & 22 (E: 8, O: 14) & 100 \\
\hline Elevated C-reactive protein & 28 (E: 19, O: 9) & 93 (E: 100, O: 78) \\
\hline Low $\mathrm{C}_{3}$ complement component & 32 (E: 19, O: 13) & 56 (E: 63, O: 46) \\
\hline Low $\mathrm{C}_{4}$ complement component & 35 (E: 22, O: 13) & 46 (E: 45, O: 46) \\
\hline Low $\mathrm{C}_{\mathrm{H} 50}$ complement component & 20 (E: 9, O: 11) & 60 (E: 67, O: 55) \\
\hline \multicolumn{3}{|l|}{ Serum autoantibodies } \\
\hline Positive antinuclear antibody & 27 (E: 16, O: 11) & 33 (E: 44, O: 18) \\
\hline Positive cryoglobulins & 19 (E: 11, O: 8) & 32 (E: 36, O: 25) \\
\hline Elevated rheumatoid factor & 19 (E: 11, O: 8) & 68 (E: 73, O: 63) \\
\hline Positive c-ANCA ${ }^{7}$ & 33 (E: 24, O: 9) & 64 (E: 63, O: 67) \\
\hline Positive antiproteinase-3 (anti-PR-3) ${ }^{8}$ & 35 (E: 24, O: 11) & 60 (E: 71, O: 36) \\
\hline Positive $\mathrm{p}$ - $\mathrm{ANCA}^{7}$ & 35 (E: 25, O: 10$)$ & 31 (E: 32, O: 30) \\
\hline Positive antimyeloperoxidase (anti-MPO) ${ }^{8}$ & 36 (E: 24, O: 12) & 39 (E: 38, O: 42) \\
\hline
\end{tabular}

E: endocarditis, O: Other infections. ${ }^{1}$ Blood hemoglobin $(\mathrm{Hgb})<13 \mathrm{gm} / \mathrm{dL}$. No difference between E and O. For all 27 subjects, mean $\mathrm{Hgb}$ was $8.4 \pm 2.5 \mathrm{gm} / \mathrm{dL}$. ${ }^{2}$ White blood cell count $(\mathrm{WBC})>10 \mathrm{k} / \mathrm{mm}^{3} .{ }^{3} \mathrm{WBC}<4 \mathrm{k} / \mathrm{mm}^{3}$. Mean WBC: E: $9.7 \pm 6.8 \mathrm{k} / \mathrm{mm}^{3}$; O: $12.1 \pm 8.5 \mathrm{k} / \mathrm{mm}{ }^{3}$. ${ }^{4}$ Neutrophil predominance and/or immature white blood cells in WBC. ${ }^{5}$ Platelet count $<100 \mathrm{k} / \mathrm{mm}^{3}$. No difference between E and O. For all 17 subjects, mean platelet count was $160 \pm 85 \mathrm{k} / \mathrm{mm}^{3}$. ${ }^{6}$ Mean erythrocyte sedimentation rate, not different between E and O, was in the 22 patients $77 \pm 29 \mathrm{~mm} / \mathrm{hr} .{ }^{7}$ Measured by immunofluorescence. ${ }^{8}$ Measured by ELISA.

TABLE 5: Renal function in 50 patients with infections, ANCA positivity, and glomerular disease.

\begin{tabular}{|c|c|c|c|}
\hline Feature & Positive patient number & Unreported patient number & Positive $\%$ of reported patients \\
\hline \multicolumn{4}{|l|}{ Urine microscopy } \\
\hline Hematuria & 31 (E 20; O 21) & $9(\mathrm{E} 7 ; \mathrm{O} 2)$ & 98 \\
\hline Dysmorphic RBCs, RBC casts & $21($ E 5, O 16) & & \\
\hline Pyuria, WBC casts & $6(\mathrm{E}: 3 ; \mathrm{O}: 3)$ & & \\
\hline \multicolumn{4}{|l|}{ Proteinuria } \\
\hline Increased urine protein excretion & 35 (E 16; O 19) & $15(\mathrm{E} 11 ; \mathrm{O} 4)$ & 100 \\
\hline Nephrotic proteinuria & $10($ E 3; O 7) & & 29 \\
\hline \multicolumn{4}{|l|}{ Renal failure } \\
\hline Elevated serum creatinine & 39 (E 20; O 19) & $9(\mathrm{E} 7 ; \mathrm{O} 2)$ & 95 \\
\hline Dialysis & $9(\mathrm{E} 5 ; \mathrm{O} 4)$ & & $18-24^{1}$ \\
\hline
\end{tabular}

\%: percent, RBC: red blood cell, WBC: white blood cell, E: endocarditis, O: other than endocarditis infection. ${ }^{1}$ Dialysis was not reported but may have been used in two patients with endocarditis and acute renal failure [36] and one patient with a chronic suppurative process who presented with a serum creatinine of $2,220 \mu \mathrm{mol} / \mathrm{L}$ [110].

The concept of "dual glomerulopathy" denotes deposition of immune complexes in the kidneys of patients with ANCAassociated pauci-immune glomerulonephritis $[129,130]$ or development of ANCA-associated pauci-immune glomerulonephritis or vasculitis in patients with immune complexmediated glomerulonephritis [131-133]. Two of the cases analyzed in this report [120, (a) and (b)] were classified by both the authors of the report and the authors of this paper as having "dual glomerulopathy" and were classified under both "pauci-immune GN" and "postinfectious GN" categories in
Tables 6 and 7. Another two cases, classified as pauci-immune glomerulonephritis or vasculitis $[112,123]$, probably had dual glomerulopathy.

ANCA formation in patients with postinfectious glomerulonephritis has been reported [134]. Whether the development of ANCA positivity without renal histological development of ANCA-mediated disease in these patients affects the severity of the renal disease remains an open question. One report found no effect [135], while another report found higher rate of crescent formation in the glomeruli 
TABLE 6: Histological types of glomerular disease, serum complement levels, and ANCA specificity in 50 patients with infections, ANCA positivity, and glomerular disease.

\begin{tabular}{|c|c|c|c|c|c|c|}
\hline Histological diagnosis & $\begin{array}{c}\text { Number of } \\
\text { patients }\end{array}$ & $\begin{array}{l}\text { Percent of } \\
\text { patients }\end{array}$ & $\begin{array}{l}\text { Low serum } \\
\text { complement }\end{array}$ & $\begin{array}{c}\text { c-ANCA and/or } \\
\text { PR3 }\end{array}$ & $\begin{array}{c}\text { p-ANCA and/or } \\
\text { MPO }\end{array}$ & $\begin{array}{c}\text { Other or } \\
\text { Nonidentified ANCA }\end{array}$ \\
\hline $\begin{array}{l}\text { Pauci-immune GN, } \\
\text { vasculitis }\end{array}$ & 23 & 45 & $5 / 10(38 \%)$ & $5 / 23(22 \%)$ & $8 / 23(35 \%)$ & $10 / 23(43 \%)$ \\
\hline Postinfectious GN & 19 & 38 & $15 / 17(88 \%)$ & $19 / 19(100 \%)$ & $1 / 19(5 \%)$ & 0 \\
\hline Anti-GMB GN & 1 & 5 & 0 & 0 & 0 & $1(100 \%)$ \\
\hline Interstitial nephritis & 5 & 10 & $4 / 5(80 \%)$ & $2 / 5(40 \%)$ & $3 / 5(60 \%)$ & 0 \\
\hline $\begin{array}{l}\text { Acute tubular } \\
\text { necrosis }\end{array}$ & 4 & 8 & $2 / 3(67 \%)$ & $2 / 4(50 \%)$ & $2 / 4(25 \%)$ & $1 / 4(25 \%)$ \\
\hline Other histology ${ }^{1}$ & 2 & 2 & 1/1 (100\%) & $1 / 2(50 \%)$ & $1 / 2(50 \%)$ & \\
\hline Nonidentified GN ${ }^{2}$ & 7 & 12 & $3 / 3(100 \%)$ & $4 / 7(57 \%)$ & $4 / 7(57 \%)$ & 0 \\
\hline
\end{tabular}

GN: glomerulonephritis, GBM: glomerular basement membrane. ${ }^{1}$ One each, focal glomerulosclerosis, chronic sclerosing glomerulonephritis. ${ }^{2}$ Immunofluorescence and electron microscopy findings were not reported. The differentiation between pauci-immune and postinfectious glomerulonephritis was not feasible from only the light microscopy picture.

TABLE 7: Treatment and outcomes of 50 patients with development of ANCA positivity and glomerulonephritis during the course of infectious episodes.

\begin{tabular}{|c|c|c|c|}
\hline Treatment method & $N(\%)$ & Outcome & $N(\%)$ \\
\hline Pauci-immune glomerulonephritis $^{1}$ & 23 & & \\
\hline Antibiotics & $10(43)$ & Improvement/recovery & $17(74)$ \\
\hline Corticosteroids & $22(96)$ & Death & $3(13)$ \\
\hline Cyclophosphamide & $17(74)$ & Not reported & $3(13)$ \\
\hline Plasma exchange & $2(9)$ & & \\
\hline Interferon-a2b & $1(4)$ & & \\
\hline Aortic valve replacement & $1(4)$ & & \\
\hline Postinfectious glomerulonephritis ${ }^{1}$ & 19 & & \\
\hline Antibiotics & $17(89)$ & Improvement/recovery & $14(74)$ \\
\hline Corticosteroids & $11(58)$ & Dialysis & $3(16)$ \\
\hline Cardiac valve replacement & $3(16)$ & Death & $5(26)$ \\
\hline Atrioventricular shunt removal & $3(16)$ & & \\
\hline Ventricular septal defect repair & $1(5)$ & & \\
\hline Intravenous immunoglobulins & $1(5)$ & & \\
\hline Plasma exchange & $1(5)$ & & \\
\hline Interferon-a2b & $1(5)$ & & \\
\hline Cyclophosphamide & $1(5)$ & & \\
\hline Other types of renal disease & 9 & - & - \\
\hline Antibiotics & $8(89)$ & Improvement/recovery & $6(67)$ \\
\hline Corticosteroids & $2(22)$ & Chronic renal failure & $2(22)$ \\
\hline Aortic valve replacement & $1(11)$ & Death & $1(11)$ \\
\hline Cyclophosphamide & $1(11)$ & & \\
\hline
\end{tabular}

${ }^{1}$ Including two patients with dual glomerulopathy [120, (a) and (b)].

of patients with postinfectious glomerulonephritis who became ANCA-positive [136]. However, the superimposition of ANCA-associated renal lesions on immune complexmediated glomerulonephritis in patients without active infections worsens the severity of renal manifestations $[130,137$, 138].

Pauci-immune and postinfectious glomerulonephritis were the most frequent histological diagnoses in Table 6 .
Figure 1 shows a pauci-immune glomerulonephritis developing a patient with bacterial endocarditis. Figure 2 shows a postinfectious glomerulonephritis. A few other findings in Table 6 are worth noticing. Some patients had more than one renal lesion (e.g., dual glomerulopathy or combination of glomerulonephritis and acute interstitial nephritis with features of tubulitis) and were classified in more than one row in this table. One patient with human immunodeficiency (HIV) 


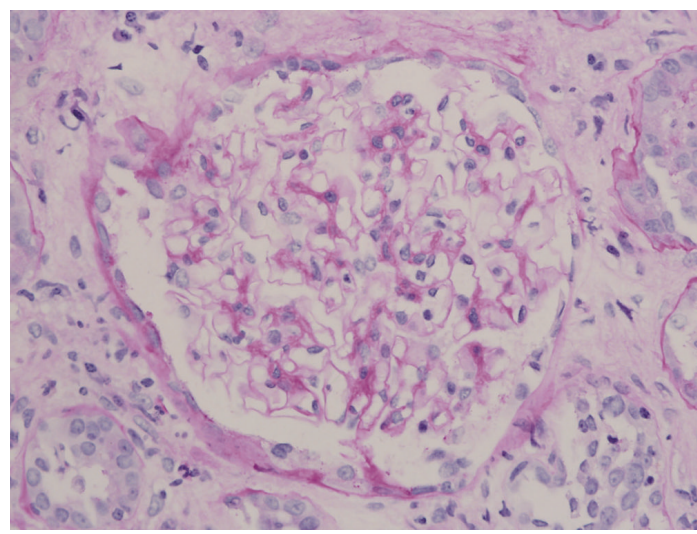

(a)

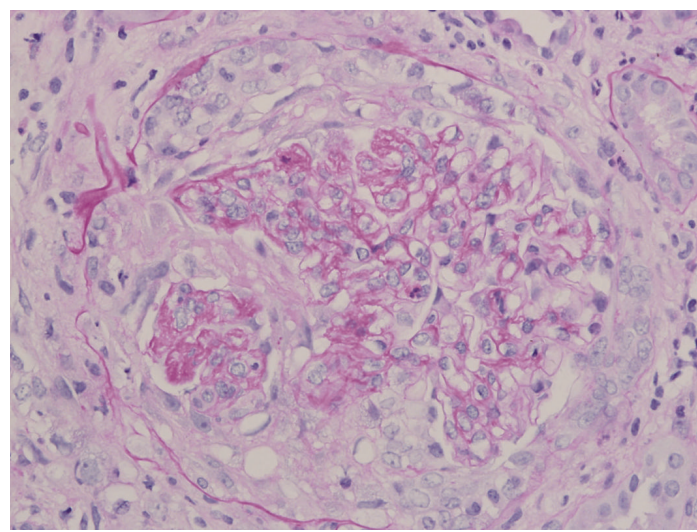

(c)

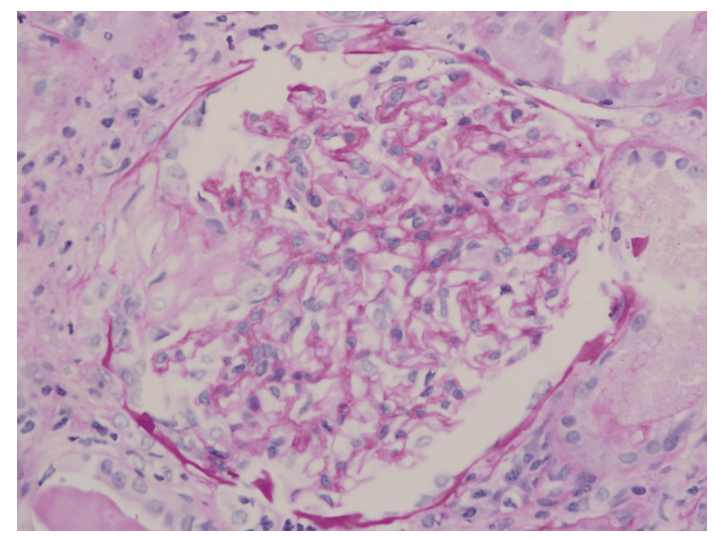

(b)

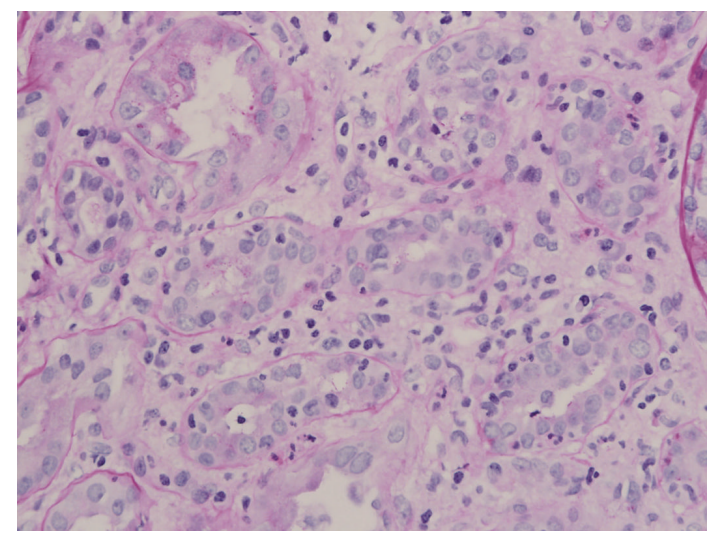

(d)

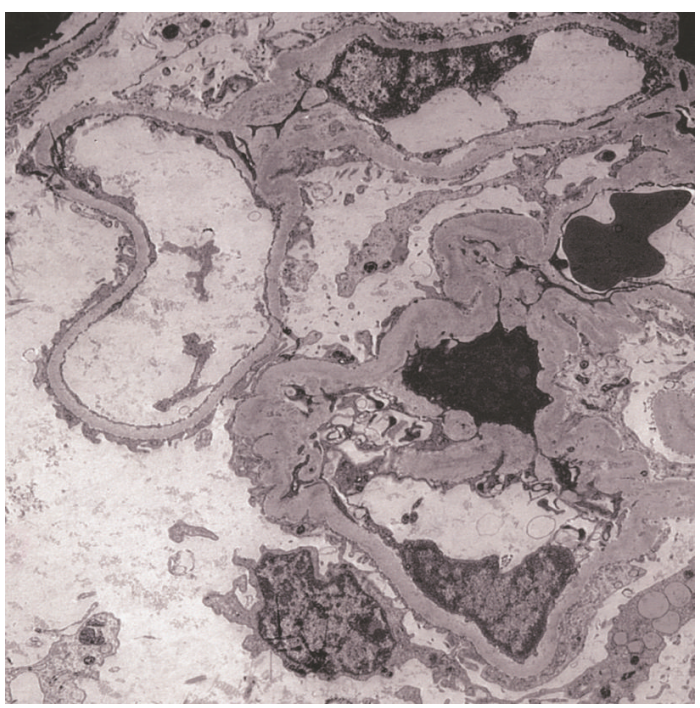

(e)

FIGURE 1: Pauci-immune glomerulonephritis and acute interstitial nephritis in a patient with ANCA triggered by infectious endocarditis. (a) Normal appearing glomerulus without endocapillary or mesangial proliferation (PAS; 400x). (b) Glomerulus with area of segmental scarring: nonscarred portion of tuft appears to be within normal limits (PAS; 400x). (c) Glomerulus with crescent formation (PAS; 400x). (d) Tubulointerstitial inflammation (PAS; 400x). (e)-(EM): Portion of tuft without significant electron densities, and without endocapillary or mesangial hypercellularity (5000x). 


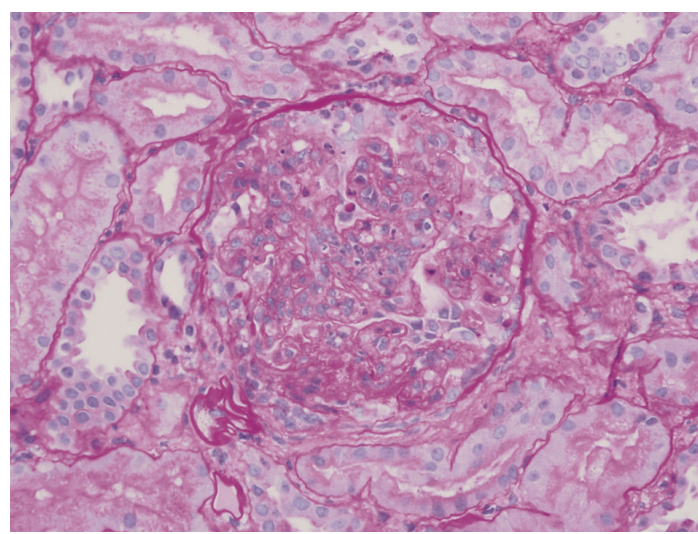

(a)

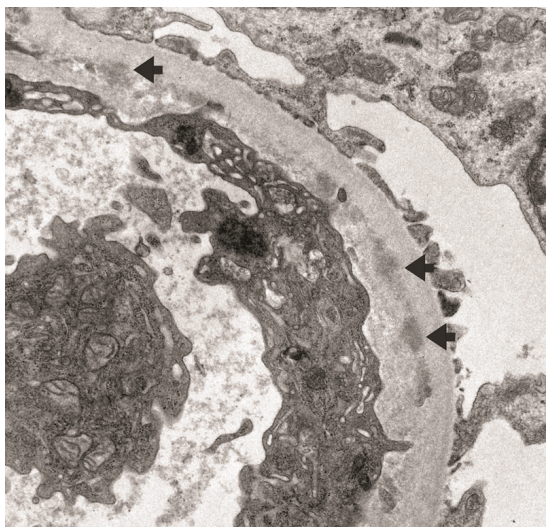

(b)

Figure 2: Postinfectious glomerulonephritis. (a) Glomerulus showing diffuse endocapillary proliferation, including intracapillary neutrophils (400x). (b)-(EM): Electron micrograph of a glomerular peripheral capillary loop showing subendothelial electron dense deposits (arrows) (6000x).

infection and multiple autoantibodies including ANCA and antibasement membrane (anti-GBM) antibodies developed anti-GBM glomerulonephritis with linear deposition of IgG and $\mathrm{C}_{3}$ on the glomerular basement membrane [121]. AntiGBM glomerulonephritis has been reported in two other patients with HIV infection [139, 140]. Finally, hypocomplementemia and positivity with c-ANCA and/or anti-PR-3 antibody were noted more frequently in patients classified in the postinfectious glomerulonephritis than those classified in the pauci-immune glomerulonephritis category. Whether this difference can be used as a differential diagnosis clue should be a subject of future studies.

\section{Diagnosis and Differential Diagnosis}

The diagnosis of ANCA-associated disease superimposed on an infection encounters obstacles. The first obstacle is the similarity of the clinical manifestations between the two categories of diseases. Malaise, weakness, fever, anorexia, weight loss, arthralgias, and myalgias are cardinal manifestations of both disease categories as are several laboratory findings including anemia, leucocytosis, and thrombocytopenia. Certain localized infections cause manifestations that may be indistinguishable from those of ANCA-associated disease. For example, auscultatory and echocardiographic features of infectious endocarditis are essentially the same as those of endocarditis caused by involvement of the cardiac valves by granulomatosis with polyangiitis [141-150]. Given the diagnostic difficulties, awareness about the possibility of formation of ANCA and other autoantibodies and performance of appropriate serological tests during the course of infections with unusual clinical features is the first step in the differential diagnosis.

The second major diagnostic difficulty is that patients with severe or complicated infections often develop multiple autoantibodies (Table 4). Autoantibodies that may become positive during infectious episodes and can be associated with specific renal diseases include, in addition to ANCA, antinuclear antibodies, antiphospholipid antibodies, antiglomerular basement membrane antibodies, and cryoglobulins. For example, HIV infection triggers the formation of multiple autoantibodies, which is associated with a substantial variety of renal diseases, and causes major diagnostic difficulties [151-153]. The diagnostic difficulties in HIV positive patients are not limited to the kidneys. Manifestations in several other organs, for example, the lungs [154], create similar diagnostic difficulties.

Given the high frequency of renal involvement during serious infectious episodes and the variety of renal pathologies that can be seen in patients with infections, renal function should be monitored with frequent urine examinations and measurements of serum creatinine concentration. If renal involvement is diagnosed, kidney biopsy with complete histological evaluation by light microscopy, immunofluorescence, and electron microscopy should be performed in a timely manner [153]. The search for exact histological diagnosis of the renal disease in patients with infections and a multiplicity of autoantibodies is important for understanding the biology of infectious processes but begs the question whether knowledge of the nature of the renal lesion will affect the management and outcome of the patient. The next section of this report addresses this issue.

\section{Treatment and Outcome}

The view that adequate treatment of the infectious process will result in cure of both the infection and the secondary immunological abnormalities without any other intervention has been expressed repeatedly. It can be argued, however, that serious manifestations mediated by autoantibodies triggered by infections require specific treatment. This second view should not be addressed in a trivial manner when ANCAassociated disease is found. The immunosuppressive measures employed in the treatment of ANCA-associated disease carry several risks, among which infection and sepsis are arguably the most important [155-157]. If these measures are applied during the course of severe infections, the risks of sepsis and septic death could increase substantially. To determine whether there is a place for measures directed against ANCA-associated disease in patients with infections 
triggering ANCA-associated glomerulonephritis, this section analyzes the treatment and outcome of the 50 patients with infections, positive ANCA and glomerular pathology.

Table 7 shows treatment, duration of followup, and outcomes of the 50 patients analyzed in this report. All but one [108] patient with pauci-immune glomerulonephritis received immunosuppressive therapy or plasma exchange. One patient [123] had cardiac valve replacement surgery. The response to treatment was not reported in three patients $[52,110]$ and $[128,(b)]$. Followup of the remaining 20 patients ranged between one week and 11 years. Among these patients, 17 (85\%) showed improvement of their clinical status or complete recovery, while ANCA, not reported in 16 patients, became negative during followup in 4 subjects (17\%). Prompt clinical response to plasma exchange [104] or cyclophosphamide plus corticosteroids [107] was noticed in two patients whose clinical picture was deteriorating, while they were receiving only antibiotics. Two other patients with hepatitis $\mathrm{C}$ and combination of immune complex glomerulonephritis and vasculitis [120, (a) and (b)] were initially treated with corticosteroids. Clinical picture and renal function improved only after addition of alpha interferon in the first patient and plasma exchange in the second. Two deaths occurred one week and 12 days after treatment with corticosteroids only or antibiotics only. It appears that death was secondary to disseminated vasculitis in the first patient [127] and to atherosclerotic coronary artery disease in the second patient [108]. Another patient, in whom the clinical and laboratory response to the treatment with corticosteroids and cyclophosphamide was not reported, died six months after diagnosis from a small bowel infarction [110]. It is not clear whether the bowel infarction was the result of vasculitis or other disease of the vessels.

Antibiotics were administered to 17 of the 19 patients with postinfectious glomerulonephritis, while 11 patients received also corticosteroids. Followup, not reported in one patient, ranged between 1 month and 4 years in the remaining 18 subjects. ANCA titer decreased or became negative in 11 patients (59\%), remained positive after 5 months in one patient (5\%) with improved clinical status, and was not reported in the remaining 7 patients. Aortic valve replacement was performed in 2 patients [111, 126], while a third patient [106] had combined aortic and mitral valve replacement. Three patients had removal of infected atrioventricular shunts and recovered promptly after surgery $[116,118,122]$. One patient [105] had repair of a ventricular septal defect four years after successful treatment. Clinical improvement or complete recovery was noted in 14 of the 19 patients (74\%). Four of the five deaths $[36,(d)],[40,(b)]$, and $[106,125]$ occurred within two months of the diagnosis, while the time of death for the other patient [111] was not reported. Death was caused by cardiac disease in two patients [40, (b)] and [125], one of whom was on maintenance hemodialysis [125] and intracerebral hemorrhage in another patient on hemodialysis [106]. The cause of death was not reported in two patients $[36,(d)]$ and [111]. Renal function improved in the third patient on hemodialysis [126], who was able to discontinue this treatment.
All but one patient with renal histology not diagnostic of either pauci-immune or postinfectious glomerulonephritis received antibiotics. Followup ranged between 6 weeks and 2.5 years. The patient who did not receive antibiotics [62] was treated successfully with corticosteroids, cyclophosphamide, and methotrexate. One patient $[36,(\mathrm{~g})]$ died 2.5 months after diagnosis, a second patient [36, (e)] developed chronic renal failure, and a third patient [36, (f)] developed end-stage renal failure. Improvement of the clinical status was noticed in seven of the nine patients. ANCA titers, not reported in 3 patients, became negative in 4 of the 6 remaining patients (67\%) and remained positive in 2 (33\%). The patient with $\mathrm{HIV}$ infection and anti-GBM glomerulonephritis required maintenance dialysis [121].

Several conclusions can be drawn from Table 7. (a) The development of ANCA positivity and glomerulonephritis in patients with infectious episodes is associated with significant morbidity (renal failure in this case) and mortality, regardless of the renal histology. (b) Pauci-immune glomerulonephritis can be treated by immunosuppressive regimens successfully and without increased incidence of sepsis. This conclusion should be interpreted with caution. The association between ANCA-mediated disease and infection with arbovirus [50] remains tentative. In addition, it is possible that the number of the patients analyzed had flares of primary ANCA-associated disease triggered by infection. Despite these reservations, treatment directed specifically against ANCA-associated disease should be given serious consideration for patients with infections, ANCA positivity, and pauci-immune glomerulonephritis or histological evidence of ANCA-associated disease in other organs. Surveillance for sepsis should be intense in patients treated with immunosuppressive regimes.

(c) Antibiotic regimen targeted against the microorganism responsible for the infection is the mainstay of management of postinfectious glomerulonephritis and is effective in most instances [158]. Corticosteroids may be added to the antibiotic regime. The efficacy and safety of adding corticosteroids in improving the renal outcome of postinfectious glomerulonephritis have not been studied in a prospective fashion. However, there are small retrospective studies [159] or case reports [160,161] supporting addition of corticosteroids in such cases. The outcomes of the patients reported in Table 7 support this conclusion.

(d) Removal of infected foreign bodies (atrioventricular shunts) or infected cardiac valves hastens recovery of both clinical and renal status. (e) Death rate appears to be higher in patients with postinfectious than those with pauci-immune glomerulonephritis. This last finding will require further studies. Factors affecting the outcomes of severe infections, such as differences in the underlying comorbidities and in the virulence of the causative infectious agents, or other factors were not studied in the reports analyzed. Studies of large numbers of patients who develop ANCA positivity and glomerulonephritis during the course of infectious episodes are needed. In addition to the histological type of the glomerulonephritis and the method of treatment, such studies should analyze other factors potentially affecting the outcomes of severe infectious episodes. 


\section{Role of Infections in the Pathogenesis of ANCA-Mediated Disease}

A body of evidence supports the view that ANCA is directly involved in the pathogenesis of pauci-immune glomerulonephritis and various vasculitides [162-165]. Infusion of anti-PR-3 ANCA into mice with humanized immune system produced vasculitic and renal lesions similar to those of granulomatosis with polyangiitis [166]. Current thinking about the role of ANCA in the pathogenesis of vasculitis is centered on activation of neutrophils by inflammatory cytokines and expression of ANCA antigens (PR-3, MPO, etc.), which are normally intracellular, on the surface of the "primed" neutrophils, where circulating ANCA can bind them. This binding activates the neutrophils and causes their adherence to vessel walls, release of proteolytic enzymes and oxygen radicals and subsequently endothelial activation, thrombin generation, and inflammatory injury to the wall of the blood vessels [167].

Epidemiological studies found an association between chronic nasal carriage of Staphylococcus aureus and granulomatosis with polyangiitis [168-170]. Chronic low-grade inflammation in the nasal cavity with release of proinflammatory cytokines, which cause priming of monocytes, has been proposed as a mechanism of triggering granulomatosis with polyangiitis by staphylococcal nasal carriage [171]. Immunization with bacterial proteins derived from Staphylococcus aureus caused ANCA formation and vasculitis in rats [172]. Infections cause both de novo ANCA formation with vasculitic lesions and relapses of established ANCA-associated disease $[68,173]$. Finally, the role of prophylactic antimicrobial regimes, mainly trimethoprim-sulfamethoxazole, in preventing relapses of granulomatosis with polyangiitis has been established [174-178].

Staphylococcal superantigen, which had been proposed as the trigger for ANCA formation, does not appear to play that role [179]. The risk for relapse of granulomatosis with polyangiitis is higher in patients carrying staphylococcal strains producing toxic-shock-syndrome-toxin-1 [180]. Patients with ANCA-associated vasculitis harbor antibodies to both PR-3 and complementary PR-3 (cPR-3), which is a peptide translated from the antisense DNA strand of PR3 [181, 182]. Several species of pathogenic micro-organisms, including Staphylococcus aureus, Entamoeba histolytica, and Ros river virus, have proteins with homology with cPR-3 [183].

Infections trigger formation of ANCA against a variety of cytoplasmic antigens, in addition to the two classical antigens PR-3 and MPO. A soluble protein in the neutrophil granules, bactericidal/permeability-increasing protein (BPI), has a role in the defense against Gram-negative bacteria. Anti-BPI autoantibodies were detected in a fraction of sera positive for ANCA by immunofluorescence and negative for MPO or PR-3 by ELISA assay [184]. Other antigens that are sources of autoantibodies recognized by immunofluorescence ANCA assay include azurocidin, which appears to be related to ANCA secondary to drugs [185], lactoferrin [185], and so forth. Anti-BPI ANCA is detected with a high frequency in patients with cystic fibrosis and infections with Pseudomonas species [53-56] and those with inflammatory bowel disease or primary sclerosing cholangiitis and presumed infections from enteric Gram-negative bacteria [186]. Anti-BPI ANCA increases the severity of both pulmonary and gastrointestinal infections through reductions of the clearance of bacteria and endotoxin by the leucocytes and, probably, through other nonspecific effects on immune complexes [187]. Whether anti-BPI ANCA is involved in the pathogenesis of vasculitis has not been clarified. The frequency of positivity for anti-BPI ANCA does not differ between patients with pauci-immune glomerulonephritis and those with other types of glomerular disease [188]. This finding indirectly suggests that anti-BPI ANCA does not have an important role in the pathogenesis of vasculitis.

Another ANCA developing in infections is an autoantibody against human lysosome-mediated membrane protein2 (LAMP-2). LAMP-2 is expressed on the membrane of the intracellular vesicles that also contain MPO and PR-3 and on the cell membrane of resting neutrophils and endothelial cells. ANCA against LAMP-2 cross-reacts with an adhesive fimbrial protein (FimH) of several species of Gram-negative bacteria. This findings suggest that molecular mimicry may be a mechanism of ANCA formation [189]. A study found that anti-LAMP-2 causes disease similar to human ANCAmediated disease in experimental animals [189]. This finding was thought to provide a new insight into the pathogenesis of ANCA-mediated diseases [190, 191]. However, another study found the same frequency of anti-LAMP-2 ANCA in patients with pauci-immune glomerulonephritis and those with other types of glomerulonephritis and failed to show that anti-LAMP-2 ANCA causes vasculitic lesions or glomerulonephritis in experimental animals [192]. Thus, although the LAMP-2 pathway remains promising, more studies are needed to clarify its role as a mechanism in ANCA-associated disease and as a link between infection and pathogenic ANCA formation [193].

Another mechanism linking infection and ANCA is through production of neutrophil extracellular traps (NETs). NETs formation, which is an important mechanism for defense against bacterial infections [194], results in a unique type of neutrophil death (NETosis), with production of chromatin webs covered by proteins, including MPO and PR-3, that trap and kill microbes [195]. Several factors, including M1 protein, lipopolysaccharides, and bacteria such as Streptococcus, Staphylococcus, and Enterococcus, which have been found with high frequencies of ANCA formation during infectious episodes (Table 3), trigger NETs formation. Contact between ANCA IgG and primed neutrophils induces formation of NETs which stick to the endothelium and cause tissue damage [196]. Both PR-3 and NETs containing elastase were detected in glomeruli of patients with ANCA-associated vasculitis and acute worsening of the renal function, who had prominent neutrophil infiltrates in their kidneys. In addition, patients with ANCA-associated vasculitis, but not control subjects, had circulating MPO-DNA complexes [196]. These findings led to the hypothesis that ANCAs perpetuate a vicious NET production maintaining the delivery of antigen-chromatin complexes to the immune system. The role of infection in this scheme is to induce NETs formation $[196,197]$. The study 
of NET formation in vasculitis [196] did not contain subjects with infections. Consequently, both the NETs hypothesis and the role of infection in it will need further study.

Another potential link between infections and ANCA formation is through toll-like receptors (TLRs) which sense pathogen-associated molecular patterns (PAMPs) such as bacterial cell wall proteins and bacterial DNA [198]. Various cell types, including neutrophils, monocytes, b-lymphocytes, endothelial cells, and epithelial cells express TLRs. TLR ligation causes release of proinflammatory cytokines, proliferation of lymphocytes, and production of antibody. In an in vitro study, stimulation of TLR9 by CPG, which are hypomethylated motifs prevalent in the DNA of bacteria, triggered production of ANCA from b-lymphocytes of patients with ANCA-associated vasculitis in remission [199]. In another study, the expression of TLR2, TLR4, and TLR9 in monocytes and natural killer cells was greater in patients with ANCA-associated disease than in healthy controls [200]. Thus, it is probable that TLRs play a role in the activation and/or relapse of ANCA-associated disease by infections. This mechanism also will need to be studied further.

Recent developments have focused on the genetics of ANCA-associated disease. Gene polymorphism and its relation to ANCA have been studied. The $\mathrm{Z}$ allele, but not the $\mathrm{S}$ deficiency allele of $\alpha_{1}$ antitrypsin, was associated with ANCAassociated vasculitis [201]. It was postulated that polymers of $\alpha_{1}$ antitrypsin, which were found in the serum and glomeruli of some patients with the $\mathrm{Z}$ allele, may promote inflammation by priming neutrophils [201]. Two other studies found associations of different types of ANCA-associated vasculitis with distinct gene variations. The first study found that both major histocompatibility-complex (MHC) and non-MHC are associated with ANCA-associated vasculitis and also that anti-PR-3 ANCA is associated with HLA-DP and the genes encoding $\alpha_{1}$ antitrypsin and PR-3, while antiMPO ANCA is associated with HLA-DQ [202]. The second study found that the PTPN22 R620W allele is associated with granulomatosis with polyangiitis, especially its anti-PR3 positive subset, but not with microscopic polyangiitis or Churg-Strauss syndrome [203]. The interaction of genetic and infectious influences on ANCA formation and ANCAmediated disease will be a new research frontier [204]. Given the association between environmental factors (exposure to silica) and ANCA-associated disease, the interaction of epigenetic and infectious factors in the pathogenesis of ANCA formation and ANCA-mediated disease could also constitute a major research focus.

\section{Conclusions}

Glomerulonephritis developing in patients who became positive for ANCA during the course of infectious episodes is associated with morbidity and mortality, regardless of its specific histological picture. It poses profound diagnostic and therapeutic challenges. Monitoring of serum creatinine, urine sediment microscopy, and proteinuria in patients with protracted or severe infections and performance of a kidney biopsy if there is an indication of kidney injury are essential steps of the diagnostic process. Evaluation of the kidney biopsy must be thorough with light microscopy, immunofluorescence, and electron microscopy components. The diagnosis of ANCA-associated glomerulonephritis poses the critical question whether specific treatment directed towards ANCA-associated disease, with its inherent risks in patients with active infections, is required or not. Evaluation of the published reports suggests that there is a place for immunosuppressive regimen in the management of patients with infections who develop ANCA-associated glomerulonephritis or vasculitis. Determination of the exact indications for this immunosuppressive regimen will require prospective studies of large numbers of patients. The association between infections, development of ANCA positivity, and development of ANCA-mediated disease is an open field for research in fundamental mechanisms of immunology and in the derangements of these mechanisms.

\section{References}

[1] R. C. Williams Jr. and H. G. Kunkel, "Rheumatoid factor, complement, and conglutinin aberrations in patients with subacute bacterial endocarditis," The Journal of Clinical Investigation, vol. 41, pp. 666-675, 1962.

[2] M. Lohlein, "Ueber haemorrhagische nierenaffectionen bei chronischer ulcerozer endocarditis," Medicinische Klinik, vol.10, pp. 375-379, 1910.

[3] K. Lange, G. Seligson, and W. Cronin, "Evidence for the in situ origin of poststreptococcal glomerulonephritis: glomerular localization of endostreptosin and the clinical significance of the subsequent antibody response," Clinical Nephrology, vol. 19, no. 1, pp. 3-10, 1983.

[4] A. S. Bayer, A. N. Theofilopoulos, and R. Eisenberg, "Circulating immune complexes in infective endocarditis," New England Journal of Medicine, vol. 295, no. 27, pp. 1500-1505, 1976.

[5] F. J. Dixon, J. D. Feldman, and J. J. Vasquez, "Experimental glomerulonephritis: the pathogenesis of a laboratory model resembling the spectrum of human glomerulonephritis," Journal of Experimental Medicine, vol. 113, pp. 899-920, 1961.

[6] R. A. Gutman, G. E. Striker, B. C. Gilliland, and R. E. Cutler, "The immune complex glomerulonephritis of bacterial endocarditis," Medicine, vol. 51, no. 1, pp. 1-25, 1972.

[7] W. G. Couser, "Mechanisms of glomerular injury in immunecomplex disease," Kidney International, vol. 28, no. 3, pp. 569583,1985

[8] G. O. Perez, N. Rothfield, and R. C. Williams, "Immune complex nephritis in bacterial endocarditis," Archives of Internal Medicine, vol. 136, no. 3, pp. 334-336, 1976.

[9] R. L. Levy and R. Hong, "The immune nature of subacute bacterial endocarditis (SBE) nephritis," The American Journal of Medicine, vol. 54, no. 5, pp. 645-652, 1973.

[10] H. K. Choi, P. A. Merkel, A. M. Walker, and J. L. Niles, "Drug-associated antineutrophil cytoplasmic antibody-positive vasculitis," Arthritis \& Rheumatism, vol. 43, pp. 405-413, 2000.

[11] H. H. Peter, D. Metzger, A. Rump, and E. Rother, "ANCA in diseases other than systemic vasculitis," Clinical and Experimental Immunology, vol. 93, no. 1, supplement, pp. 12-14, 1993.

[12] L. Nassberger, A. G. Sjoholm, H. Jonsson, G. Sturfelt, and A. Akesson, "Autoantibodies against neutrophil cytoplasm components in systemic lupus erythematosus and in hydralazineinduced lupus," Clinical and Experimental Immunology, vol. 81, no. 3, pp. 380-383, 1990. 
[13] N. Makita, H. Katori, F. Takemoto et al., "A case of mixed connective tissue disease (MCTD) complicated with MPO-ANCArelated necrotizincj gloomerulonephritis," Clinical Nephrology, vol. 54, no. 2, pp. 164-168, 2000.

[14] D. Bansi, R. W. Chapman, and K. Fleming, "Antineutrophil cytoplasmic antibodies in chronic liver diseases: prevalence, titre, specificity and IgG subclass," Journal of Hepatology, vol. 24, no. 5, pp. 581-586, 1996.

[15] R. H. Duerr, S. R. Targan, C. J. Landers et al., "Neutrophil cytoplasmic antibodies: a link between primary sclerosing cholangitis and ulcerative colitis," Gastroenterology, vol. 100, no. 5 I, pp. 1385-1391, 1991.

[16] D. Zauli, S. Ghetti, A. Grassi et al., "Anti-neutrophilcytoplasmic antibodies in type 1 and 2 autoimmune hepatitis," Hepatology, vol. 25, no. 5, pp. 1105-1107, 1997.

[17] Y. Hosoya, S. Minota, A. Lefor et al., "Resolution of antineutrophil cytoplasmic antibody-associated vasculitis after resection of gastric cancer," Modern Rheumatology, vol. 20, no. 1, pp. 102-105, 2010.

[18] T. Cil, A. Altintas, A. Isikdogan, and S. Batun, "Prevalence of antineutrophil cytoplasmic antibody positivity in patients with Hodgkin's and non-Hodgkin lymphoma: a single center experience," International Journal of Hematology, vol. 90, no. 1, pp. 52-57, 2009.

[19] K. Tsuruoka, S. Sekiya, T. Yokoyama et al., "MPO-ANCA related vasculitis complicating mucinous cystadenoma of the pancreas and severe acute pancreatitis after steroid pulse therapy: a case report," Japanese Journal of Nephrology, vol. 50, no. 7, pp. 948953, 2008.

[20] M. Wong, J. Grossman, B. H. Hahn, and A. La Cava, "Cutaneous vasculitis in breast cancer treated with chemotherapy," Clinical Immunology, vol. 129, no. 1, pp. 3-9, 2008.

[21] J. G. Parambil, K. A. Keogh, F. C. Fervenza, and J. H. Ryu, "Microscopic polyangiitis associated with thymoma, exacerbating after thymectomy," American Journal of Kidney Diseases, vol. 48, no. 5, pp. 827-831, 2006.

[22] S. D. Navaneethan, J. Taylor, B. Goldman, and A. Bose, "Antineutrophil cytoplasmic antibody associated crescentic IgA nephropathy in hematopoietic stem cell transplantation," Clinical Nephrology, vol. 71, no. 1, pp. 59-62, 2009.

[23] B. Terjung and U. Spengler, "Atypical p-ANCA in PSC and AIH: a hint toward a "leaky gut"?" Clinical Reviews in Allergy and Immunology, vol. 36, no. 1, pp. 40-51, 2009.

[24] Y. Wada, T. Kuroda, A. Murasawa, M. Nakano, and I. Narita, "Anti-neutrophil cytoplasmic autoantibodies against bactericidal/permeability-increasing protein in patients with rheumatoid arthritis and their correlation with bronchial involvement," Modern Rheumatology, vol. 20, no. 3, pp. 252-256, 2010.

[25] L. Harper and C. O. Savage, "ANCA-associated renal vasculitis at the end of the twentieth century-a disease of older patients," Rheumatology, vol. 44, no. 4, pp. 495-501, 2005.

[26] C. A. Langford, "Cyclophosphamide as induction therapy for Wegener's granulomatosis and microscopic polyangiitis," Clinical and Experimental Immunology, vol. 164, no. 1, supplement, pp. 31-34, 2011.

[27] F. Rees, R. Yazdani, and P. Lanyon, "Long-term follow-up of different refractory systemic vasculitides treated with rituximab," Clinical Rheumatology, vol. 30, pp. 1241-1245, 2011.

[28] A. Majumdar, S. Chowdhary, M. A. S. Ferreira et al., "Renal pathological findings in infective endocarditis," Nephrology Dialysis Transplantation, vol. 15, no. 11, pp. 1782-1787, 2000.
[29] J. I. Zeledon, R. L. McKelvey, K. S. Servilla et al., "Histological varieties and treatment of glomerulonephritis causing acute renal failure during the course of bacterial infections," International Urology and Nephrology, vol. 40, no. 2, pp. 461-470, 2008.

[30] R. J. L. Klaassen, R. Goldschmeding, K. M. Dolman et al., "Antineutrophil cytoplasmic autoantibodies in patients with symptomatic HIV infection," Clinical and Experimental Immunology, vol. 87, no. 1, pp. 24-30, 1992.

[31] F. Bonnet, J. J. Pineau, J. L. Taupin et al., "Prevalence of cryoglobulinemia and serological markers of autoimmunity in human immunodeficiency virus infected individuals: a crosssectional study of 97 patients," Journal of Rheumatology, vol. 30, no. 9, pp. 2005-2010, 2003.

[32] L. H. Calabrese, "Infection with the human immunodeficiency virus type 1 and vascular inflammatory disease," Clinical and Experimental Rheumatology, vol. 22, no. 6, pp. S87-S93, 2004.

[33] A. Kamat, P. Ancuta, R. S. Blumberg, and D. Gabuzda, "Serological markers for inflammatory bowel disease in aids patients with evidence of microbial translocation," PLOS ONE, vol. 5, no. 11, Article ID e15533, 2010.

[34] H. K. Choi, P. Lambrecht, K. L. Niles, W. L. Gross, and P. A. Merkel, "Subacute bacterial endocarditis with positive antineutrophil cytoplasmic antibodies and anti-proteinase 3 antibodies," Arthritis \& Rheumatism, vol. 43, pp. 226-231, 2000.

[35] A. De Corla-Souza and B. A. Cunha, "Streptococcal viridans subacute bacterial endocarditis associated with antineutrophil cytoplasmic autoantibodies (ANCA)," Heart and Lung, vol. 32, no. 2, pp. 140-143, 2003.

[36] B. Bonaci-Nikolic, S. Andrejevic, M. Pavlovic, Z. Dimcic, B. Ivanovic, and M. Nikolic, "Prolonged infections associated with antineutrophil cytoplasmic antibodies specific to proteinase 3 and myeloperoxidase: diagnostic and therapeutic challenge," Clinical Rheumatology, vol. 29, no. 8, pp. 893-904, 2010.

[37] L. Guillevin, H. Visser, F. Oksman, and J. Pourrat, "Antineutrophil cytoplasmic antibodies in polyarteritis nodosa related to hepatitis B virus," Arthritis and Rheumatism, vol. 33, no. 12, pp. 1871-1872, 1990.

[38] L. Guillevin, H. Visser, L. H. Noel et al., "Antineutrophil cytoplasm antibodies in systemic polyarteritis nodosa with and without hepatitis B virus infection and Churg-Strauss syndrome-62 patients," Journal of Rheumatology, vol. 20, no. 8, pp. 1345-1349, 1993.

[39] R. Kasmani, K. Okoli, K. Naraharisetty, W. Gunning, J. I. Shapiro, and S. Ratnam, "Microscopic polyangiitis triggered by recurrent methicillin-resistant Staphylococcus aureus bacteremia," International Urology and Nephrology, vol. 42, no. 3, pp. 821-824, 2010.

[40] S. P. McAdoo, C. Densem, A. Salama, and C. D. Pusey, "Bacterial endocarditis associated with proteinase 3 anti-neutrophil cytoplasm antibody," NDT Plus, vol. 4, no. 3, pp. 208-210, 2011.

[41] J. Romani, L. Puig, and J. N. De Moragas, "Detection of antineutrophil cytoplasmic antibodies in patients with hepatitis $\mathrm{C}$ virus-induced cutaneous vasculitis with mixed cryoglobulinemia," Archives of Dermatology, vol. 132, no. 8, pp. 974-975, 1996.

[42] H. Ohira, J. Tojo, J. Shinzawa et al., "Antineutrophil cytoplasmic antibody in patients with antinuclear antibody-positive chronic hepatitis C," Fukushima Journal of Medical Science, vol. 44, no. 2, pp. 83-92, 1998.

[43] P. Lamprecht, O. Gutzeit, E. Csernok et al., "Prevalence of ANCA in mixed cryoglobulinemia and chronic hepatitis $\mathrm{C}$ 
virus infection," Clinical and Experimental Rheumatology, vol. 21, no. 6, pp. S89-S94, 2003.

[44] M. Cojocaru, I. M. Cojocaru, and S. A. Iacob, "Prevalence of anti-neutrophil cytoplasmic antibodies in patients with chronic hepatitis C infection associated mixed cryoglobulinemia," Romanian Journal of Internal Medicine, vol. 44, no. 4, pp. 427431, 2006.

[45] T. N. K. Chou, T. C. Hsu, R. M. Chen, L. I. Lin, and G. J. Tsay, "Parvovirus B19 infection associated with the production of antineutrophil cytoplasmic antibody (ANCA) and anticardiolipin antibody (aCL)," Lupus, vol. 9, no. 7, pp. 551-554, 2000.

[46] J. Hermann, U. Demel, D. Stünzner, E. Daghofer, G. Tilz, and W. Graninger, "Clinical interpretation of antineutrophil cytoplasmic antibodies: parvovirus B19 infection as a pitfall," Annals of the Rheumatic Diseases, vol. 64, no. 4, pp. 641-643, 2005.

[47] C. M. Magro, R. Wusirika, G. E. Frambach, G. J. Nuovo, C. Ferri, and P. Ross, "Autoimmune-like pulmonary disease in association with parvovirus B19: a clinical, morphologic, and molecular study of 12 cases," Applied Immunohistochemistry and Molecular Morphology, vol. 14, no. 2, pp. 208-216, 2006.

[48] P. von Landenberg, H. W. Lehmann, and S. Modrow, "Human parvovirus B19 infection and antiphospholipid antibodies," Autoimmunity Reviews, vol. 6, no. 5, pp. 278-285, 2007.

[49] K. Satake, I. Ohsawa, N. Kobayashi et al., "Three cases of PR3ANCA positive subacute bacterial endocarditis caused by attenuated bacteria (Propionibacterium, Gemella, and Bartonella) complicated with kidney injury," Modern Rheumatology, vol. 21, pp. 536-541, 2011.

[50] D. J. Davies, J. E. Moran, J. F. Niall, and G. B. Ryan, "Segmental necrotising glomerulonephritis with antineutrophil antibody: possible arbovirus aetiology?" British Medical Journal, vol. 285, no. 6342 , article $606,1982$.

[51] A. Bauer, W. J. Jabs, S. Süfke, M. Maass, and B. Kreft, "Vasculitic purpura with antineutrophil cytoplasmic antibodypositive acute renal failure in a patient with Streptococcus bovis and Neisseria subflava bacteremia and subacute endocarditis," Clinical Nephrology, vol. 62, no. 2, pp. 144-148, 2004.

[52] A. Steitz, T. Orth, A. Feddersen, T. Fischer, E. Marker-Hermann, and M. Husmann, "A case of endocarditis with vasculitis due to Actinobacillus actinomycetemcomitans: a $16 \mathrm{~S}$ rDNA signature for distinction from related organisms," Clinical Infectious Diseases, vol. 27, no. 1, pp. 224-225, 1998.

[53] R. Mahadeva, A. C. Dunn, R. C. Westerbeek et al., "Antineutrophil cytoplasmic antibodies (ANCA) against bactericidal/permeability-increasing protein (BPI) and cystic fibrosis lung disease," Clinical and Experimental Immunology, vol. 117, no. 3, pp. 561-567, 1999.

[54] E. Carmona, F. Perez-Aguilar, J. A. Lopez, J. Ferrer-Calvete, and J. M. Sanchez-Cuenca, "Anti-neutrophil-cytoplasmic autoantibodies (ANCA) in 105 patients (56 adults and 49 children) suffering from cystic fibrosis, attending a Spanish hospital," Journal of Internal Medicine, vol. 252, no. 3, pp. 281-282, 2002.

[55] L. Dorlöchter, M. Carlsson, E. J. Olafsdottir, O. D. RoØksund, K. Rosendahl, and G. Fluge, "Anti-neutrophil cytoplasmatic antibodies and lung disease in cystic fibrosis," Journal of Cystic Fibrosis, vol. 3, no. 3, pp. 179-183, 2004.

[56] M. Rotschild, N. Elias, D. Berkowitz et al., "Autoantibodies against bactericidal/permeability-increasing protein (BPIANCA) in cystic fibrosis patients treated with azithromycin," Clinical and Experimental Medicine, vol. 5, no. 2, pp. 80-85, 2005.
[57] O. Cohavy, D. Bruckner, L. K. Gordon et al., "Colonic bacteria express an ulcerative colitis pANCA-related protein epitope," Infection and Immunity, vol. 68, no. 3, pp. 1542-1548, 2000.

[58] H. Locht, E. Peen, and T. Skogh, "Antineutrophil cytoplasmic antibodies in reactive arthritis," Journal of Rheumatology, vol. 22, no. 12, pp. 2304-2306, 1995.

[59] K. Zycinska, K. A. Wardyn, Z. Zycinski, and R. Smolarczyk, "Correlation between Helicobacter pylori infection and pulmonary wegener's granulomatosis activity," Journal of Physiology and Pharmacology, vol. 59, no. 6, pp. 845-851, 2008.

[60] H. Schultz, E. Csernok, S. Nikkari, P. Toivanen, A. Toivanen, and W. L. Gross, "BPI-ANCA is found in reactive arthritis caused by Yersinia and Salmonella infection and recognise exclusively the C-terminal part of the BPI molecule," Scandinavian Journal of Rheumatology, vol. 29, no. 4, pp. 226-231, 2000.

[61] C. Bechara, M. Gousseff, A. Passeron et al., "Corynebacterium jeikeium pacemaker infection associated with antineutrophil cytoplasmic antibodies: a single positive blood culture could be sufficient for diagnosis," Journal of Medical Microbiology, vol. 60, no. 2, pp. 249-251, 2011.

[62] J. Park, S. Banno, Y. Sugiura et al., "Microscopic polyangiitis associated with diffuse panbronchiolitis," Internal Medicine, vol. 43, no. 4, pp. 331-335, 2004.

[63] E. K. Bell, S. S. Chugh, and W. J. Cook, "A case of infection-associated antiproteinase-3-negative cytoplasmic antineutrophil cytoplasmic antibody pauci-immune focal necrotizing glomerulonephritis," Nephrology Dialysis Transplantation, vol. 25, no. 9, pp. 3119-3123, 2010.

[64] K. Trcko, P. B. Marko, and J. Milijkovic, "Leucocytoclastic vasculitis induced by Mycoplasma pneumoniae infection," Acta Dermatovenerologica Croatica, vol. 20, pp. 118-121, 2012.

[65] M. Iyoda, T. Hato, K. Matsumoto et al., "Rapidly progressive glomerulonephritis in a patient with Chlamydia pneumoniae infection: a possibility of superantigenic mechanism of its pathogenesis," Clinical Nephrology, vol. 65, no. 1, pp. 48-52, 2006.

[66] M. Iyoda, A. Kuroki, and T. Sugisaki, "Chlamydia pneumoniae infection and MPO-ANCA-associated glomerulonephritis," Nephrology Dialysis Transplantation, vol. 22, no. 3, pp. 965966, 2007.

[67] M. Fujita, S. Hatachi, and M. Yagita, "Acute Chlamydia pneumoniae infection in the pathogenesis of autoimmune diseases," Lupus, vol. 18, no. 2, pp. 164-168, 2009.

[68] G. Cabiddu, P. Altieri, A. Pani et al., "Mediterranean spotted fever with acute renal failure simulating a relapse in C-ANCA vasculitis," Nephron, vol. 79, no. 2, pp. 241-242, 1998.

[69] A. Garcia-Zamalloa, N. Gurruchaga, and M. Montes, "Q fever and antineutrophil cytoplasmic antibodies," American Journal of Medicine, vol. 108, no. 8, pp. 687-688, 2000.

[70] R. O. Holmes Jr., J. D. Hartzell, J. K. Tofferi, J. D. Roebuck, and W. F. Kelly, "Dual high titer antineutrophil cytoplasmic autoantibodies in association with systemic Q fever," Journal of Clinical Rheumatology, vol. 15, no. 8, pp. 411-413, 2009.

[71] W. Wöckel, K. Häußinger, R. Weis, and A. Morresi-Hauf, "Anticytoplasmatic antibody (cANCA) in syphilitic gumma of the lung," Deutsche Medizinische Wochenschrift, vol. 121, no. 19, pp. 617-621, 1996.

[72] A. Constantin, F. Marin, F. Oksman, and G. Bouteiller, "Antineutrophil cytoplasmic antibodies in leptospirosis," The Journal of Rheumatology, vol. 23, no. 2, article 411, 1996. 
[73] B. F. A. Freire, A. A. F. Ferraz, E. Nakayama, S. Ura, and T. T. Queluz, "Anti-neutrophil cytoplasmic antibodies (ANCA) in the clinical forms of leprosy," International Journal of Leprosy, vol. 66, no. 4, pp. 475-482, 1998.

[74] F. Medina, A. Camargo, J. Moreno, A. Zonana-Nacach, J. Aceves-Avila, and A. Fraga, "Anti-neutrophil cytoplasmic autoantibodies in leprosy," British Journal of Rheumatology, vol. 37, no. 3, pp. 270-273, 1998.

[75] O. Cohavy, G. Harth, M. Horwitz et al., "Identification of a novel mycobacterial histone $\mathrm{H} 1$ homologue (HupB) as an antigenic target of pANCA monoclonal antibody and serum immunoglobulin A from patients with Crohn's disease," Infection and Immunity, vol. 67, no. 12, pp. 6510-6517, 1999.

[76] V. D. Pradhan, S. S. Badakere, K. Ghosh, and A. R. Pawar, "Spectrum of anti-neutrophil cytoplasmic antibodies in patients with Pulmonary Tuberculosis overlaps with that of Wegener's granulomatosis," Indian Journal of Medical Sciences, vol. 58, no. 7, pp. 283-288, 2004.

[77] S. Chaiamnuay and L. W. Heck, "Antineutrophil cytoplasmic antibody vasculitis associated with Mycobacterium avium intracellulare infection," Journal of Rheumatology, vol. 32, no. 8, pp. 1610-1612, 2005.

[78] F. L. B. Edington, M. O. A. R. Bacellar, P. R. Machado et al., "Anti-neutrophil cytoplasmic antibodies in leprosy," Clinical Rheumatology, vol. 26, no. 2, pp. 208-210, 2007.

[79] S. Faruqi, J. A. Kastelik, and D. V. McGivern, "Diagnostic pitfall: Mycobacterium avium complex pulmonary infection and positive ANCA," European Journal of Internal Medicine, vol. 19, no. 3, pp. 216-218, 2008.

[80] K. Ghosh, V. Pradhan, and K. Ghosh, "Background noise of infection for using ANCA as a diagnostic tool for vasculitis in tropical and developing countries," Parasitology Research, vol. 102, no. 5, pp. 1093-1095, 2008.

[81] R. Sherkat, K. Mostafavizadeh, L. Zeydabadi, P. Shoaei, and S. Rostani, "Antineutrophil cytoplasmic antibodies in patients with pulmonary tuberculosis," Iranian Journal of Immunology, vol. 8, pp. 52-57, 2011.

[82] M. Kontic, S. Radovanovic, M. Nicolic, and B. Bonaci-Nicolic, "Concomitant drug- and infection-induced antineutrophil cytoplasmic autoantibody (ANCA)-associated vasculitis with multispecific ANCA," Medical Practice, vol. 21, pp. 488-491, 2012.

[83] A. M. Milesi-Lecat, O. Aumaitre, T. Deusebis et al., "Semiinvasive pulmonary aspergillosis with anti-neutrophil cytoplasmic auto-antibodies: two cases," Annales de Medecine Interne, vol. 145, no. 2, pp. 140-146, 1994.

[84] C. Cho, A. Asuncion, and A. H. Tatum, "False-positive antineutrophil cytoplasmic antibody in aspergillosis with oxalosis," Archives of Pathology and Laboratory Medicine, vol. 119, no. 6, pp. 558-561, 1995.

[85] T. Akimoto, O. Saito, M. Inoue et al., "Rapid formation of Aspergillus mycetoma in a patient receiving corticosteroid treatment. Serial radiographic observation over two months," Internal Medicine, vol. 46, no. 11, pp. 733-738, 2007.

[86] T. Saito, N. Shime, K. Itoh et al., "Disseminated aspergillosis following resolution of Pneumocystis pneumonia with sustained elevation of beta-glucan in an intensive care unit: a case report," Infection, vol. 37, no. 6, pp. 547-550, 2009.

[87] G. E. Mead, D. Wilks, K. McLaren, and R. J. Fergusson, "Oral histoplasmosis: a case report," Journal of Infection, vol. 37, no. 1, pp. 73-75, 1998.
[88] R. P. Byrd, J. Hourany, C. Cooper, and T. M. Roy, "False-positive antineutrophil cytoplasmic antibodies in a patient with cavitary pulmonary sporotrichosis," American Journal of Medicine, vol. 104, no. 1, pp. 101-103, 1998.

[89] R. H. Evans, C. Gelder M, A. P. Smith, and A. R. Freedman, "Pneumocystis carinii pneumonia mimicking Wegener's granulomatosis," Clinical Infectious Diseases, vol. 28, no. 5, pp. 1163$1164,1999$.

[90] N. Takeda, H. Ichiyasu, A. Kijima, D. Notsute, N. Saita, and H. Kohrogi, "A case of AIDS with Pneumocystis jirovecii pneumonia which required differentiation from ANCA-related lung disease," Nihon Kokyuki Gakkai Zasshi, vol. 49, pp. 929935, 2011.

[91] I. Stappaerts, J. Bogers, D. Ebo, E. Vanden Broecke, W. J. Stevens, and P. Vermeire, "c-ANCA positivity in a Belgian patient with pulmonary paracoccidioidomycosis," European Respiratory Journal, vol. 10, no. 10, pp. 2419-2422, 1997.

[92] C. Hartman, R. Eliakim, and R. Shamir, "Perinuclear antineutrophil cytoplasmic autoantibodies and anti-Saccharomyces cerevisiae antibodies: serologic markers in inflammatory bowel disease," Israel Medical Association Journal, vol. 6, no. 4, pp. 221226, 2004.

[93] G. E. Reese, V. A. Constantinides, C. Simillis et al., "Diagnostic precision of anti-Saccharomyces cerevisiae antibodies and perinuclear antineutrophil cytoplasmic antibodies in inflammatory bowel disease," American Journal of Gastroenterology, vol. 101, no. 10, pp. 2410-2422, 2006.

[94] D. J. Pudifin, J. Duursma, V. Gathiram, and T. F. H. G. Jackson, "Invasive amoebiasis is associated with the development of antineutrophil cytoplasmic antibody," Clinical and Experimental Immunology, vol. 97, no. 1, pp. 48-51, 1994.

[95] S. Arslan, A. Bakkaloglu, G. Oksuzoglu et al., "The value of pANCA as a serological marker in diagnosing the coexistence of chronic active invasive amebic colitis and ulcerative colitis," American Journal of Gastroenterology, vol. 90, no. 12, pp. 22652266, 1995.

[96] C. Wenisch, H. Wenisch, H. Bankl -C et al., "Detection of anti-neutrophil cytoplasmic antibodies after acute Plasmodium falciparum malaria," Clinical and Diagnostic Laboratory Immunology, vol. 3, pp. 132-134, 1996.

[97] T. M. Yahya, S. Benedict, A. Shalabi, and R. Bayoumi, "Antineutrophil cytoplasmic antibody (ANCA) in malaria is directed against cathepsin G," Clinical and Experimental Immunology, vol. 110, no. 1, pp. 41-44, 1997.

[98] V. Pradhan, S. S. Badakere, U. Shankarkumar, Y. S. Iyer, K. Ghosh, and D. Karnad, "Anti-neutrophil Cytoplasmic Antibodies (ANCA) in Malaria," Indian Journal of Malariology, vol. 39, no. 3-4, pp. 51-59, 2002.

[99] E. Brahn, D. A. Pegues, Q. Yao, and N. Craft, "Mucocutaneous leishmaniasis masquerading as wegener granulomatosis," Journal of Clinical Rheumatology, vol. 16, no. 3, pp. 125-128, 2010.

[100] F. G. De Rosa, A. Amoroso, A. Teggi et al., "Anti-neutrophil cytoplasmic antibodies in Echinococcus granulosus hydatid disease," Human Immunology, vol. 62, no. 10, pp. 1122-1126, 2001.

[101] M. Rajapurkar, U. Hegde, M. Rokhade, S. Gang, and K. Gohel, "Respiratory hyperinfection with Strongyloides stercoralis in a patient with renal failure," Nature Clinical Practice Nephrology, vol. 3, no. 10, pp. 573-577, 2007.

[102] S. Kaya, M. Demirci, E. Sesli Cetin et al., "Investigation of the presence of autoantibodies in patients with toxocariasis," Mikrobiyoloji Bülteni, vol. 43, pp. 661-666, 2009. 
[103] J. Wagner, K. Andrassy, and E. Ritz, "Is vasculitis in subacute bacterial endocarditis associated with ANCA?" Lancet, vol. 337, no. 8744, pp. 799-800, 1991.

[104] L. Couzi, D. Morel, C. Deminière, and P. Merville, "An unusual endocarditis-induced crescentic glomerulonephritis treated by plasmapheresis," Clinical Nephrology, vol. 62, no. 6, pp. 461-465, 2004.

[105] M. Fukuda, M. Motokawa, T. Usami et al., "PR3-ANCA-positive crescentic necrotizing glomerulonephritis accompanied by isolated pulmonic valve infective endocarditis, with reference to previous reports of renal pathology," Clinical Nephrology, vol. 66, no. 3, pp. 202-209, 2006.

[106] N. Kishimoto, Y. Mori, H. Yamahara et al., "Cytoplasmic antineutrophil cytoplasmic antibody positive pauci-immune glomerulonephritis associated with infectious endocarditis," Clinical Nephrology, vol. 66, no. 6, pp. 447-454, 2006.

[107] K. N. Konstantinov, A. A. Harris, M. F. Hartshorne, and A. H. Tzamaloukas, "Symptomatic anti-neutrophil cytoplasmic antibody-positive disease complicating subacute bacterial endocarditis: to treat or not to treat?" Case Reports in Nephrology and Urology, vol. 2, pp. 25-32, 2012.

[108] R. Angangco, S. Thiru, and D. B. G. Oliveira, "Pauciimmune glomerulonephritis associated with bacterial infection," Nephrology Dialysis Transplantation, vol. 8, no. 8, pp. 754756, 1993.

[109] W. Hanf, J. E. Serre, J. H. Salmon et al., "Glomerulonephrite rapidement progressive a ANCA revelant une endocardite infectieuse subaigue (Rapidly progressive ANCA positive glomerulonephritis as the presenting feature of infectious endocarditis)," La Revue de Médecine Interne, vol. 32, pp. el16-el18, 2011.

[110] B. Chan, V. d'Intini, and J. Savige, "Anti-neutrophil cytoplasmic antibody (ANCA)-associated microscopic polyangiitis following a suppurative wound infection," Nephrology Dialysis Transplantation, vol. 21, no. 10, pp. 2993-2994, 2006.

[111] M. Uh, I. A. McCormick, and J. T. Kelsall, "Positive cytoplasmic antineutrophil cytoplasmic antigen with PR3 specificity glomerulonephritis in a patient with subacute bacterial endocarditis," Journal of Rheumatology, vol. 38, no. 7, pp. 1527-1528, 2011.

[112] J. F. Viallard, S. Bonnet, L. Couzi et al., "Glomerulonephritis caused by Actinobacillus actinomycetemcomitans mimicking cANCA-positive vasculitis," Nephrology Dialysis Transplantation, vol. 17, no. 4, pp. 663-665, 2002.

[113] H. Sugiyama, M. Sahara, Y. Imai et al., "Infective endocarditis by Bartonella quintana masquerading as antineutrophil cytoplasmic antibody-associated small vessel vasculitis," Cardiology, vol. 114, no. 3, pp. 208-211, 2009.

[114] S. H. Forbes, S. C. Robert, J. E. Martin, and R. Rajakariar, "Acute kidney injury with hematuria, a positive ANCA test, and low levels of complement," American Journal of Kidney Diseases, vol. 59, pp. 26-31, 2012.

[115] A. Y. Elzouki, M. Akthar, and K. Mirza, "Brucella endocarditis associated with glomerulonephritis and renal vasculitis," Pediatric Nephrology, vol. 10, no. 6, pp. 748-751, 1996.

[116] H. Bonarek, F. Bonnet, C. Delclaux, C. Deminière, V. De Précigout, and M. Aparicio, "Reversal of c-ANCA positive mesangiocapillary glomerulonephritis after removal of an infected cysto-atrial shunt," Nephrology Dialysis Transplantation, vol. 14, no. 7, pp. 1771-1773, 1999.
[117] Y. Iwata, S. Ohta, K. Kawai et al., "Shunt nephritis with positive titers for ANCA specific for proteinase 3," American Journal of Kidney Diseases, vol. 43, no. 5, pp. ell-e16, 2004.

[118] T. Nagashima, D. Hirata, H. Yamamoto, H. Okazaki, and S. Minota, "Antineutrophil cytoplasmic autoantibody specific for proteinase 3 in a patient with shunt nephritis induced by Gemella morbillorum," American Journal of Kidney Diseases, vol. 37, no. 5, article E38, 2001.

[119] H. Takato, M. Yasui, Y. Waseda, N. Sakai, T. Wada, and M. Fujimura, "A case of microscopic polyangiitis following mycoplasma infection in a patient with MPO-ANCA positive pulmonary fibrosis," Allergology International, vol. 60, no. 1, pp. 93-96, 2011.

[120] P. Lamprecht, W. H. Schmitt, and W. L. Gross, "Mixed cryoglobulinaemia, glomerulonephritis, and ANCA: essential cryoglobulinaemic vasculitis or ANCA-associated vasculitis?" Nephrology Dialysis Transplantation, vol. 13, no. 1, pp. 213-221, 1998.

[121] E. J. B. Monteiro, D. Caron, C. A. Balda, M. Franco, A. B. Pereira, and G. M. Kirsztajn, "Anti-glomerular basement membrane glomerulonephritis in an HIV positive patient: case report," Brazilian Journal of Infectious Diseases, vol. 10, no. 1, pp. 55-58, 2006.

[122] J. H. Song, K. J. Lee, S. W. Lee, J. Y. Han, and M. J. Kim, “Fatal pulmonary-renal syndrome manifested with immune complex crescentic glomerulonephritis in a patient with MPO-ANCA seropositivity," Yonsei Medical Journal, vol. 42, no. 4, pp. 425430, 2001.

[123] T. Messiaen, C. Lefebvre, F. Zech, J. P. Cosyns, and M. Jadoul, "ANCA-positive rapidly progressive glomerulonephritis: there may be more to the diagnosis than you think!" Nephrology Dialysis Transplantation, vol. 12, no. 4, pp. 839-841, 1997.

[124] J. F. Subra, C. Michelet, J. Laporte et al., "The presence of cytoplasmic antineutrophil cytoplasmic antibodies (C-ANCA) in the course of subacute bacterial endocarditis with glomerular involvement, coincidence or association?" Clinical Nephrology, vol. 49, no. 1, pp. 15-18, 1998.

[125] T. Haseyama, H. Imai, A. Komatsuda et al., "Proteinase3-antineutrophil cytoplasmic antibody (PR3-ANCA) positive crescentic glomerulonephritis in a patient with Down's syndrome and infectious endocarditis," Nephrology Dialysis Transplantation, vol. 13, no. 8, pp. 2142-2146, 1998.

[126] K. Osafune, H. Takeoka, H. Kanamori et al., "Crescentic glomerulonephritis associated with infective endocarditis: renal recovery after immediate surgical intervention," Clinical and Experimental Nephrology, vol. 4, no. 4, pp. 329-334, 2000.

[127] K. Y. Wang, S. Shimajirt, T. Yoshida, S. Yamada, and Y. Sasagurt, "An autopsy case of microscopic polyangiitis associated with bacterial endocarditis," Journal of University of Occupational and Environmental Health, vol. 32, no. 3, pp. 273-279, 2010.

[128] D. Sitara and B. I. Hoffbrand, "Chronic bronchial suppuration and antineutrophil cytoplasmic antibody (ANCA) positive systemic vasculitis," Postgraduate Medical Journal, vol. 66, no. 778, pp. 669-671, 1990.

[129] M. Haas and J. A. Eustace, "Immune complex deposits in ANCA-associated crescentic glomerulonephritis: a study of 126 cases," Kidney International, vol. 65, no. 6, pp. 2145-2152, 2004.

[130] F. Yu, M. Chen, S. X. Wang, W. Z. Zou, M. H. Zhao, and H. Y. Wang, "Clinical and pathological characteristics and outcomes of Chinese patients with primary anti-neutrophil cytoplasmic 
antibodies-associated systemic vasculitis with immune complex deposition in kidney," Nephrology, vol. 12, no. 1, pp. 74-80, 2007.

[131] L. Cavagna, R. Caporali, C. Esposito, C. Augetti, O. Epis, and C. Montecucco, "Clinical features of ANCA-positive systemic lupus erythematosus: report of two cases," Scandinavian Journal of Rheumatology, vol. 36, no. 1, pp. 74-76, 2007.

[132] Y. Hirai, M. Iyoda, T. Shibata et al., "Lupus nephritis associated with positive MPO-ANCA in a patient with underlying autoimmune hemolytic anemia," Clinical and Experimental Nephrology, vol. 12, no. 5, pp. 393-397, 2008.

[133] S. H. Nasr, V. D. D’Agati, H.-R. Park et al., "Necrotizing and crescentic lupus nephritis with antineutrophil cytoplasmic seropositivivity," Clinical Journal of the American Society of Nephrology, vol. 3, pp. 682-690, 2008.

[134] S. Mezzano, G. Valderrama, F. Olavarria et al., "Antineutrophilcytoplasmic-autoantibodies in poststreptococcal nephritis," Advances in Experimental Medicine and Biology, vol. 336, pp. 449-453, 1993.

[135] A. Waters, V. Langlois, P. Thorner, and D. Geary, "Atypical p-ANCA is not a poor prognostic marker in postinfectious glomerulonephritis," Pediatric Nephrology, vol. 22, no. 9, pp. 1383-1386, 2007.

[136] L. G. Ardiles, G. Valderrama, P. Moya, and S. A. Mezzano, "Incidence and studies on antigenic specificities of antineutrophil-cytoplasmic autoantibodies (ANCA) in poststreptococcal glomerulonephritis," Clinical Nephrology, vol. 47, no. 1, pp. 1-5, 1997.

[137] I. Neumann, H. Regele, R. Kain, R. Birck, and F. T. Meisl, "Glomerular immune deposits are associated with increased proteinuria in patients with ANCA-associated crescentic nephritis," Nephrology Dialysis Transplantation, vol. 18, no. 3, pp. 524-531, 2003.

[138] S. H. Nasr, S. M. Said, A. M. Valeri et al., "Membranous glomerulonephritis with ANCA-associated necrotizing and crescentic glomerulonephritis," Clinical Journal of the American Society of Nephrology, vol. 4, no. 2, pp. 299-308, 2009.

[139] E. Wechsler, T. Yang, S. C. Jordan, A. Vo, and C. C. Nast, "Antiglomerular basement membrane disease in an HIV-infected patient," Nature Clinical Practice Nephrology, vol. 4, no. 3, pp. 167-171, 2008.

[140] P. Singh, M. Barry, and A. Tzamaloukas, "Goodpasture's disease complicating human immunodeficiency virus infection," Clinical Nephrology, vol. 76, pp. 74-77, 2011.

[141] A. Davenport, J. Goodfellow, S. Goel, A. G. Maciver, and P. Walker, "Aortic valve disease in patients with Wegener's granulomatosis," American Journal of Kidney Diseases, vol. 24, no. 2, pp. 205-208, 1994.

[142] A. D. Fox and S. E. Robbins, "Aortic valvulitis complicating Wegener's granulomatosis," Thorax, vol. 49, no. 11, pp. 1176-1177, 1994.

[143] S. C. D. Grant, R. D. Levy, M. C. Venning, C. Ward, and N. H. Brooks, "Wegener's granulomatosis and the heart," British Heart Journal, vol. 71, no. 1, pp. 82-86, 1994.

[144] N. E. R. Goodfield, S. Bhandari, W. D. Plant, A. Morley-Davies, and G. R. Sutherland, "Cardiac involvement in Wegener's granulomatosis," British Heart Journal, vol. 73, no. 2, pp. 110-115, 1995.

[145] R. D. Leff, "Acute aortic insufficiency associated with Wegener granulomatosis," Mayo Clinic Proceedings, vol. 74, no. 9, pp. 897899, 1999.
[146] P. Bruno, C. Le Hello, M. Massetti et al., "Necrotizing granulomata of the aortic valve in Wegener's disease," Journal of Heart Valve Disease, vol. 9, no. 5, pp. 633-635, 2000.

[147] J. M. Mishell, "Cases from the Osler Medical Service at Johns Hopkins University," American Journal of Medicine, vol. 113, no. 7, pp. 607-609, 2002.

[148] M. Calachanis, P. Ferrero, F. Orzan, F. Marchisio, and G. Trevi, "Vasculitis mimicking bacterial endocarditis," Italian Heart Journal, vol. 4, no. 11, pp. 816-818, 2003.

[149] C. Stöllberger, J. Finsterer, G. J. Zlabinger et al., "Antineutrophil cytoplasmic autoantibody-negative antiproteinase 3 syndrome presenting as vasculitis, endocarditis, polyneuropathy and Dupuytren's contracture," Journal of Heart Valve Disease, vol. 12, no. 4, pp. 530-534, 2003.

[150] S. Ramakrishnan, R. Narang, G. C. Khilnani et al., "Wegener's granulomatosis mimicking prosthetic valve endocarditis," Cardiology, vol. 102, no. 1, pp. 35-36, 2004.

[151] J. A. Savige, L. Chang, S. Horn, and S. M. Crowe, "Anti-nuclear, anti-neutrophil cytoplasmic and anti-glomerular basement membrane antibodies in HIV-infected individuals," Autoimmunity, vol. 18, no. 3, pp. 205-211, 1994.

[152] G. T. Hernandez, J. M. Critchfield, and R. A. Rodriguez, "Interpretation of serologic tests in an HIV-infected patient with kidney disease," Nature Clinical Practice Nephrology, vol. 2, no. 12, pp. 708-712, 2006.

[153] L. A. Szczech, A. Anderson, C. Ramers et al., "The uncertain significance of anti-glomerular basement membrane antibody among HIV-infected persons with kidney disease," American Journal of Kidney Diseases, vol. 48, no. 4, pp. e55-e59, 2006.

[154] M. P. Muthiah, "New lung lesion in immunocompromised host-correct diagnosis despite a false positive ANCA," Southern Medical Journal, vol. 99, no. 7, pp. 701-702, 2006.

[155] M. Koselj-Kajtna, M. Koselj, T. Rott, A. Kandus, and A. Bren, "Infectious complications of immunosuppressive treatment for anti-neutrophil cytoplasm antibody-related vasculitis," Transplantation Proceedings, vol. 34, no. 7, pp. 3001-3002, 2002.

[156] C. Charlier, C. Henegar, O. Launay et al., "Risk factors for major infections in Wegener granulomatosis: analysis of 113 patients," Annals of the Rheumatic Diseases, vol. 68, no. 5, pp. 658-663, 2009.

[157] J. G. McGregor, S. L. Hogan, Y. Hu, C. E. Jennette, R. J. Falk, and P. H. Nachman, "Glucocorticoids and relapse and infection rates in anti-neutrophil cytoplasmic antibody disease," Clinical Journal of the American Society of Nephrology, vol. 7, pp. 240247,2012

[158] Y. Nagaba, Y. Hiki, T. Aoyama et al., "Effective antibiotic treatment of methicillin-resistant Staphylococcus aureus-associated glomerulonephritis," Nephron, vol. 92, no. 2, pp. 297-303, 2002.

[159] D. Jovanović, Z. Kovacević, V. Rabrenović, and V. Skatarić, "Acute post-streptococcal glomerulonephritis in adultscorticosteroid therapy, yes or no?" Vojnosanitetski Pregled, vol. 58, no. 2, pp. 161-166, 2001.

[160] V. Le Moing, F. Lacassin, M. Delahousse et al., "Use of corticosteroids in glomerulonephritis related to infective endocarditis: three cases and review," Clinical Infectious Diseases, vol. 28, no. 5, pp. 1057-1061, 1999.

[161] D. Koya, K. Shibuya, R. Kikkawa, and M. Haneda, "Successful recovery of infective endocarditis-induced rapidly progressive glomerulonephritis by steroid therapy combined with antibiotics: a case report," BMC Nephrology, vol. 5, article 18, 2004.

[162] A. S. Wiik, "Autoantibodies in ANCA-associated vasculitis," Rheumatic Disease Clinics, vol. 36, pp. 479-489, 2010. 
[163] C. G. M. Kallenberg, "Pathogenesis of ANCA-associated vasculitides," Annals of the Rheumatic Diseases, vol. 70, no. 1, supplement, pp. i59-i63, 2011.

[164] N. Lepse, W. H. Abdulahad, C. G. M. Kallenberg, and P. Heeringa, "Immune regulatory mechanisms in ANCAassociated vasculitides," Autoimmunity Reviews, vol. 11, pp. 7783,2011 .

[165] M. M. van Timmeren and P. Heeringa, "Pathogenesis of ANCAassociated vasculitis: recent insights from animal models," Current Opinion in Rheumatology, vol. 24, pp. 8-14, 2012.

[166] M. A. Little, B. Al-Ani, S. Ren et al., "Anti-proteinase 3 anti-neutrophil cytoplasm autoantibodies recapitulate systemic vasculitis in mice with a humanized immune system," PLoS One, vol. 7, Article ID e28626, 2012.

[167] Y. Hong, D. Eleftheriou, A. A. Hussain et al., "Anti-neutrophil cytoplasmic antibodies stimulate release on neutrophil microparticles," Journal of the American Society of Nephrology, vol. 23, pp. 49-62, 2012.

[168] C. A. Stegeman, J. W. C. Tervaert, W. J. Sluiter, W. L. Manson, P. E. De Jong, and C. G. M. Kallenberg, "Association of chronic nasal carriage of Staphylococcus aureus and higher relapse rates in Wegener granulomatosis," Annals of Internal Medicine, vol. 120, no. 1, pp. 12-17, 1994.

[169] M. Laudien, S. D. Gadola, R. Podschun et al., "Nasal carriage of Staphylococcus aureus and endonasal activity in Wegener's granulomatosis as compared to rheumatoid arthritis and chronic rhinosinusitis with nasal polyps," Clinical and Experimental Rheumatology, vol. 28, supplement 57, pp. 51-55, 2010.

[170] E. R. Popa, C. A. Stegeman, C. G. M. Kallenberg, and J. W. C. Tervaert, "Staphylococcus aureus and Wegener's granulomotosis," Arthritis Research, vol. 4, no. 2, pp. 77-79, 2002.

[171] M. Chen and C. G. M. Kallenberg, "ANCA-associated vasculitides-advances in pathogenesis and treatment," Nature Reviews Rheumatology, vol. 6, no. 11, pp. 653-664, 2010.

[172] J. Savige, L. Nassis, T. Cooper, B. Paspaliaris, P. Martinello, and D. MacGregor, "Antineutrophil cytoplasmic antibody (ANCA)associated systemic vasculitis after immunization with bacterial proteins," Clinical and Experimental Rheumatology, vol. 20, pp. 783-789, 2002.

[173] H. Tadema, W. H. Abdulahad, N. Lepse, C. A. Stegeman, C. G. M. Kallenberg, and P. Heeringa, "Bacterial DNA motifs trigger ANCA production in ANCA-associated vasculitis in remission," Rheumatology, vol. 50, no. 4, pp. 689-696, 2011.

[174] R. A. DeRemee, T. J. McDonald, and L. H. Weiland, "Wegener's granulomatosis: observations on treatment with antimicrobial agents," Mayo Clinic Proceedings, vol. 60, no. 1, pp. 27-32, 1985.

[175] B. C. West, J. R. Todd, and J. W. King, "Wegener granulomatosis and trimethoprim-sulfamethoxazole: complete remission after a twenty-year course," Annals of Internal Medicine, vol. 106, no. 6, pp. 840-842, 1987.

[176] H. L. Israel, "Sulfamethoxazole-trimethoprim therapy for Wegener's granulomatosis," Archives of Internal Medicine, vol. 148, no. 10, pp. 2293-2295, 1988.

[177] C. A. Stegeman, J. W. C. Tervaert, P. E. De Jong, and C. G. M. Kallenberg, "Trimethoprim-sulfamethoxazole (Co-trimoxazole) for the prevention of relapses of Wegener's granulomatosis," New England Journal of Medicine, vol. 335, no. 1, pp. 16-20, 1996.

[178] C. G. M. Kallenberg, "What is the evidence for prophylactic antibiotic treatment in patients with systemic vasculitides?" Current Opinion in Rheumatology, vol. 23, no. 3, pp. 311-316, 2011.
[179] E. R. Popa, C. A. Stegeman, N. A. Bos, C. G. M. Kallenberg, and J. W. Cohen Tervaert, "Staphylococcal superantigens and $\mathrm{T}$ cell expansions in Wegener's granulomatosis," Clinical and Experimental Immunology, vol. 132, no. 3, pp. 496-504, 2003.

[180] E. R. Popa, C. A. Stegeman, W. H. Abdulahad et al., "Staphylococcal toxic-shock-syndrome-toxin-1 as a risk factor for disease relapse in Wegener's granulomatosis," Rheumatology, vol. 46, no. 6, pp. 1029-1033, 2007.

[181] W. F. Pendergraft, G. A. Preston, R. R. Shah et al., "Autoimmunity is triggered by cPR-3(105-201), a protein complementary to human autoantigen proteinase-3," Nature Medicine, vol. 10, no. 1, pp. 72-79, 2004.

[182] P. Hewins, F. Belmonte, J. Charles Jennette, R. J. Falk, and G. A. Preston, "Longitudinal studies of patients with ANCA vasculitis demonstrate concurrent reactivity to complementary $\mathrm{PR} 3$ protein segments $\mathrm{CPR} 3 \mathrm{~m}$ and $\mathrm{CPR} 3 \mathrm{C}$ and with no reactivity to cPR3N," Autoimmunity, vol. 44, no. 2, pp. 98-106, 2011.

[183] J. C. Jennette, R. J. Falk, and A. H. Gasim, "Pathogenesis of antineutrophil cytoplasmic autoantibody vasculitis," Current Opinion in Nephrology and Hypertension, vol. 20, no. 3, pp. 263270, 2011.

[184] M. H. Zhao, S. J. Jones, and C. M. Lockwood, "Bactericidal/ permeability-increasing protein (BPI) is an important antigen for anti-neutrophil cytoplasmic autoantibodies (ANCA) in vasculitis," Clinical and Experimental Immunology, vol. 99, no. 1, pp. 49-56, 1995.

[185] M. H. Zhao and C. M. Lockwood, "Azurocidin is a novel antigen for anti-neutrophil cytoplasmic autoantibodies (ANCA) in systemic vasculitis," Clinical and Experimental Immunology, vol. 103, no. 3, pp. 397-402, 1996.

[186] M. P. Stoffel, E. Csernok, C. Herzberg, T. Johnston, S. F. Carroll, and W. L. Gross, "Anti-neutrophil cytoplasmic antibodies (ANCA) directed against bactericidal/permeability increasing protein (BPI): a new seromarker for inflammatory bowel disease and associated disorders," Clinical and Experimental Immunology, vol. 104, no. 1, pp. 54-59, 1996.

[187] H. Schultz, "From infection to autoimmunity: a new model for induction of ANCA against the bactericidal/permeability increasing protein (BPI)," Autoimmunity Reviews, vol. 6, no. 4, pp. 223-227, 2007.

[188] J. J. Yang, R. Tuttle, R. J. Falk, and J. C. Jennette, "Frequency of anti-bactericidal/permeability-increasing protein (BPI) and anti-azurocidin in patients with renal disease," Clinical and Experimental Immunology, vol. 105, no. 1, pp. 125-131, 1996.

[189] R. Kain, M. Exner, R. Brandes et al., "Molecular mimicry in pauci-immune focal necrotizing glomerulonephritis," Nature Medicine, vol. 14, no. 10, pp. 1088-1096, 2008.

[190] X. Bosch and E. Mirapeix, "LAMP-2 illuminates pathogenesis of ANCA glomerulonephritis," Nature Reviews Nephrology, vol. 5, no. 5, pp. 247-249, 2009.

[191] A. D. Salama and C. D. Pusey, "Shining a LAMP on pauciimmune focal segmental glomerulonephritis," Kidney International, vol. 76, no. 1, pp. 15-17, 2009.

[192] A. J. Roth, M. C. Brown, E. N. Smith et al., "Anti-LAMP-2 antibodies are not prevalent in patients with antineutrophil cytoplasmic antibody glomerulonephritis," Journal of the American Society of Nephrology, vol. 23, pp. 545-555, 2012.

[193] S. M. Flint and C. O. Savage, "Anti-LAMP-2 autoantibodies in ANCA-associated pauci-immune glomerulonephritis," Journal of the American Society of Nephrology, vol. 23, pp. 378-380, 2012. 
[194] V. Brinkmann, U. Reichard, C. Goosmann et al., "Neutrophil extracellular traps kill bacteria," Science, vol. 303, no. 5663, pp. 1532-1535, 2004.

[195] T. A. Fuchs, U. Abed, C. Goosmann et al., "Novel cell death program leads to neutrophil extracellular traps," Journal of Cell Biology, vol. 176, no. 2, pp. 231-241, 2007.

[196] K. Kessenbrock, M. Krumbholz, U. Schönermarck et al., "Netting neutrophils in autoimmune small-vessel vasculitis," Nature Medicine, vol. 15, no. 6, pp. 623-625, 2009.

[197] X. Bosch, "LAMPs and NETs in the pathogenesis of ANCA vasculitis," Journal of the American Society of Nephrology, vol. 20, no. 8, pp. 1654-1656, 2009.

[198] T. Kawai and S. Akira, "The role of pattern-recognition receptors in innate immunity: update on toll-like receptors," Nature Immunology, vol. 11, no. 5, pp. 373-384, 2010.

[199] H. Tadema, W. H. Abdulahad, N. Lepse, C. A. Stegeman, C. G. M. Kallenberg, and P. Heeringa, "Bacterial DNA motifs trigger ANCA production in ANCA-associated vasculitis in remission," Rheumatology, vol. 50, no. 4, pp. 689-696, 2011.

[200] H. Tadema, W. H. Abdulahad, C. A. Stegeman, C. G. M. Kallenberg, and P. Heeringa, "Increased expression of Tolllike receptors by monocytes and natural killer cells in ANCAassociated vasculitis," PLoS One, vol. 6, no. 9, Article ID e24315, 2011.

[201] H. Morris, M. D. Morgan, A. M. Wood et al., "ANCA-associated vasculitis is linked to carriage of the $\mathrm{Z}$ allele of $\alpha 1$ antitrypsin and its polymers," Annals of the Rheumatic Diseases, vol. 70, pp. 1851-1856, 2011.

[202] P. A. Lyons, T. F. Rayner, S. Trivedi et al., "Genetically distinct subsets within ANCA-associated vasculitis," New England Journal of Medicine, vol. 367, pp. 214-223, 2012.

[203] D. Martorana, F. Maritati, and G. Malebra, "PTRN22 R620W polymorphism in the ANCA-associated vasculitides," Rheumatology, vol. 51, pp. 805-812, 2012.

[204] L. C. Willcocks, P. A. Lyons, A. J. Rees, and K. G. C. Smith, "The contribution of genetic variation and infection to the pathogenesis of ANCA-associated systemic vasculitis," Arthritis Research and Therapy, vol. 12, no. 1, article 202, 2010. 


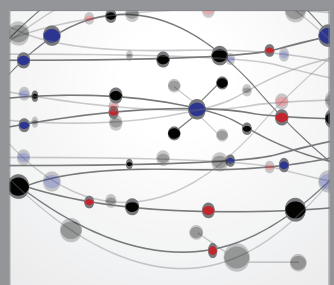

The Scientific World Journal
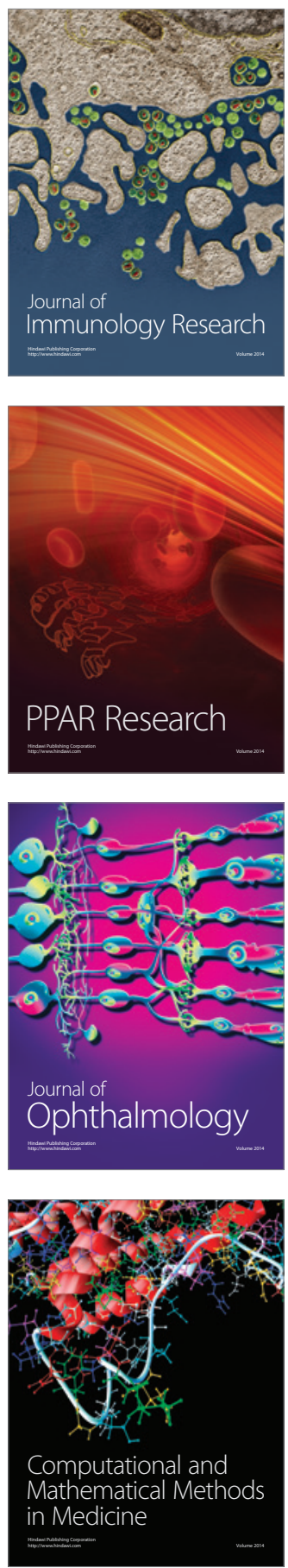

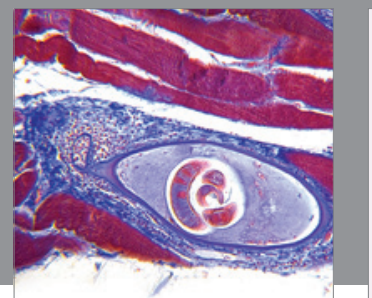

Gastroenterology

Research and Practice
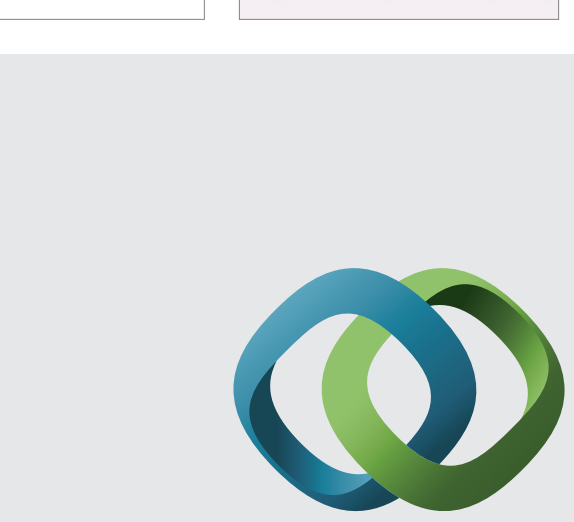

\section{Hindawi}

Submit your manuscripts at

http://www.hindawi.com
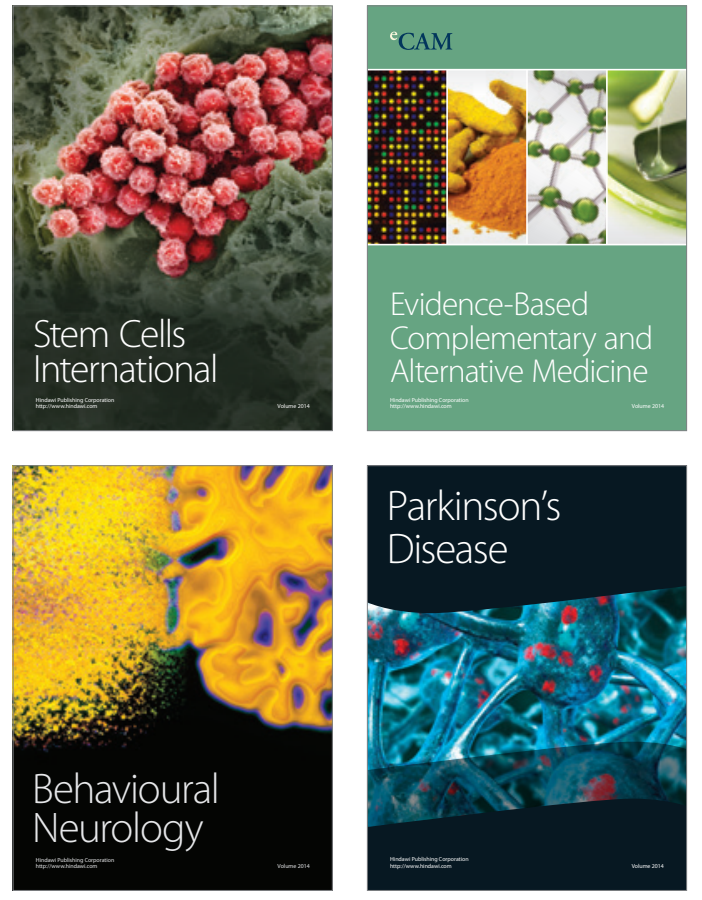
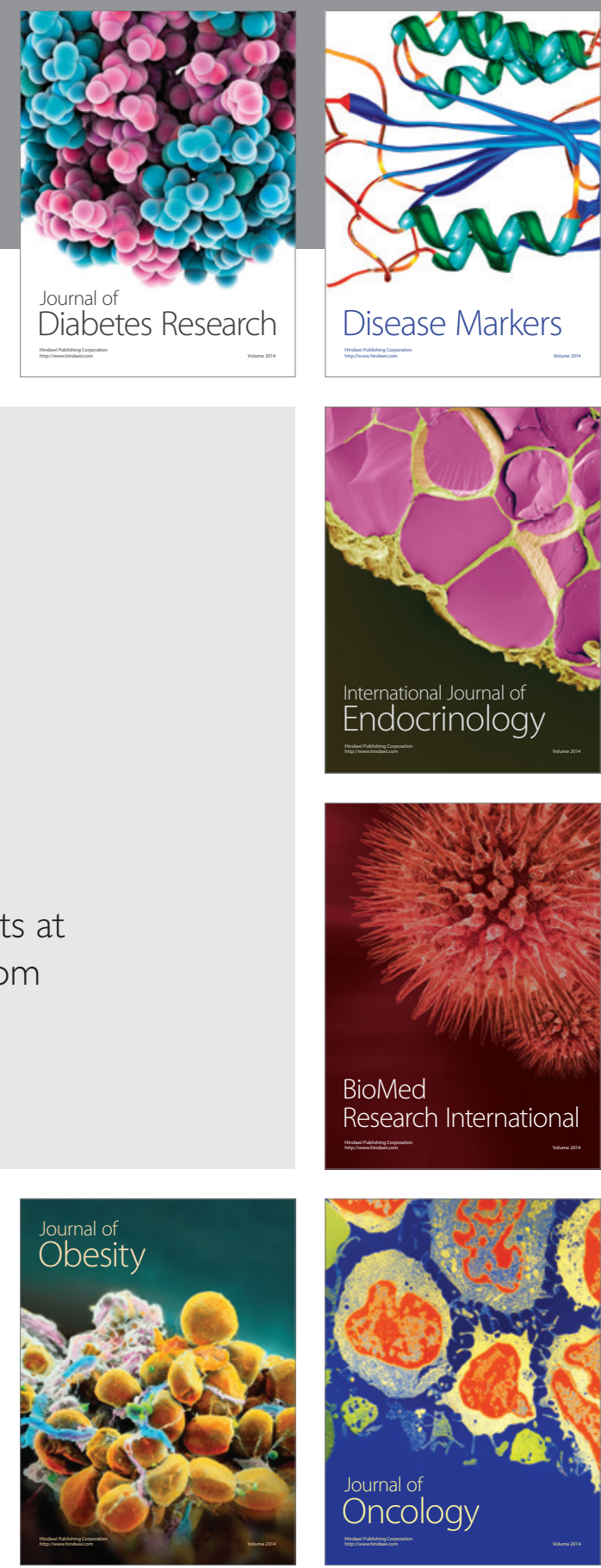

Disease Markers
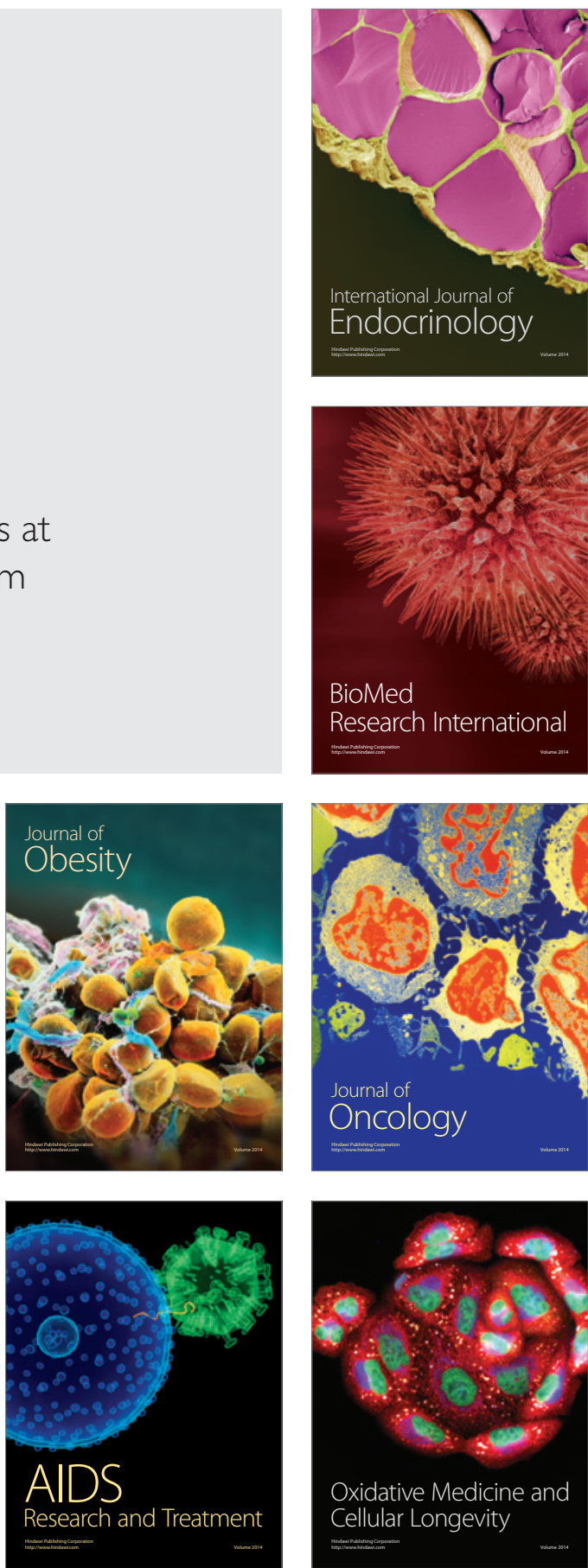